University of Rhode Island

DigitalCommons@URI

$12-23-2015$

\title{
IMMIGRATION ATTITUDES AND SUPPORT FOR THE WELFARE STATE IN THE AMERICAN MASS PUBLIC
}

James C. Garand

Ping Xu

University of Rhode Island, pingxu@uri.edu

Belinda C. Davis

Follow this and additional works at: https://digitalcommons.uri.edu/psc_facpubs

The University of Rhode Island Faculty have made this article openly available.

Please let us know how Open Access to this research benefits you.

This is a pre-publication author manuscript of the final, published article.

Terms of Use

This article is made available under the terms and conditions applicable towards Open Access

Policy Articles, as set forth in our Terms of Use.

Citation/Publisher Attribution

Garand, J. C., Xu, P. and Davis, B. C. (2017), Immigration Attitudes and Support for the Welfare State in the American Mass Public. American Journal of Political Science, 61: 146-162. doi:10.1111/ajps.12233

Available at: https://doi.org/10.1111/ajps.12233

This Article is brought to you for free and open access by the Political Science at DigitalCommons@URI. It has been accepted for inclusion in Political Science Faculty Publications by an authorized administrator of DigitalCommons@URI. For more information, please contact digitalcommons-group@uri.edu. 


\title{
IMMIGRATION ATTITUDES AND SUPPORT FOR THE WELFARE STATE IN THE AMERICAN MASS PUBLIC
}

\author{
James C. Garand \\ Louisiana State University \\ Ping Xu \\ University of Rhode Island \\ Belinda C. Davis \\ Louisiana State University
}

An earlier version of this paper was presented at the 2014 annual meeting of the Midwest Political Science Association, Chicago Illinois, April 3-6, 2014. We are indebted to Matthew Hitt, Brian Krueger, Marc Hutchison, Rene Rocha, and anonymous referees for their advice and constructive comments on this paper. The responsibility for any errors remains with the authors. 


\title{
IMMIGRATION ATTITUDES AND SUPPORT FOR THE WELFARE STATE IN THE AMERICAN MASS PUBLIC
}

\begin{abstract}
In this paper we explore the relationship between Americans' attitudes toward immigrants and immigration and their attitudes toward welfare. Using data from the Cumulative American National Election Study (CANES) from 1992-2012, we find ample evidence of the influence of immigration attitudes on both individuals' attitudes toward welfare recipients and their attitudes toward increased welfare spending. These immigration effects persist even in face of statistical controls for attitudes toward African Americans and attitudes toward the poor; indeed, in our models the magnitude of the effects of immigration attitudes surpasses the magnitude of effects of attitudes toward blacks and the poor. Further, our finding of immigration effects withstands a range of robustness tests. Our findings point to the possible "immigrationalization" of Americans' welfare attitudes and provide strong evidence that how Americans think about immigration and immigrants is a major factor in how they think about welfare.
\end{abstract}

Word count: 8,929 
Over the last several decades, the United States has witnessed a substantial increase in its immigrant population. From 1970 to 2007, the foreign-born population quadrupled in the United States and exceeded one fifth of the total population in several states (Census 1999; Census 2007). This large influx of immigrants has led to profound social, political, and economic changes in American life and has drawn considerable attention from both scholars and policy makers. Concern that immigrants will place a heavy burden on the social safety net has prompted many Americans to question the degree to which immigrants in the United States should be given access to the panoply of programs that comprise the social welfare state.

Compared to its European counterparts, the United States is known to have a less generous welfare state and a public that is less enthusiastic about welfare. Scholars have considered a variety of explanations for the relative reluctance of Americans to support an expanded welfare state, but one explanation suggests that the lack of enthusiasm for welfare among Americans can be traced to the racial divide between whites and blacks (Quadagno 1994; Gilens 2000; Alesina and Glaeser 2004). The argument is that white Americans' perceptions that blacks are lazy and heavily rely on welfare assistance directly result in their low levels of welfare support (Gilens 2000). More recent empirical studies also find that in neighborhoods, cities, and states with higher racial diversity, public support for welfare is lower and public goods provisions are also less generous (Alesina, Baqir and Easterly 1999; Luttmer 2001; Alesina and Glaeser 2004).

While there is little doubt that the black-white racial divide in American society has played at least some role in shaping support for the welfare state, we suggest that the recent large influx of immigrants has caused fundamental changes in America's demographic landscape and influenced Americans' views about the modern welfare state and its role in shaping the social safety net. We argue here that the American welfare state today has become more "immigrationalized" than "racialized," insofar as how Americans think about immigration has now become an important explanation for welfare support in 
America. As a starting point, we explore the linkage between Americans' attitudes toward immigration and immigrants and their attitudes toward the welfare state. We use data from the Cumulative American National Election Study (CANES) for selected years from 1992 to 2012 to estimate a series of models that permit us to analyze the connection between attitudes toward immigrants, on one hand, and support for greater welfare spending and favorable attitudes toward welfare recipients, on the other. Our findings point to the strong and consistent effect of immigration attitudes in shaping individuals' views toward the American welfare state.

\section{IMMIGRATION IN THE UNITED STATES}

The United States has witnessed a substantial increase in the immigrant population over the past four decades. Based on the trend in the foreign-born population in the United States from 1850 to 2010 (see Figure 1), one can see that the percentage of the population comprised of immigrants decreased steadily from a high of $14.7 \%$ in 1910 to a low of $4.7 \%$ in 1970 , but since then the immigrant population has increased substantially to a recent high of $12.9 \%$ in 2010 (U.S. Census, 2013). Moreover, while there is considerable variation across the American states in the rate of growth in the immigrant population, most states-in fact, all but three-have experienced an increase in their immigrant population percentage. In Table 1 we present data on the immigrant population percentage in each state from 1996 and 2008, which illustrates the substantial growth in states like Georgia, Kentucky and Tennessee where the foreign born population more than tripled. In 2008, the foreign-born population exceeded one fifth of the population in six states-California (33.5\%), New Jersey (25.9\%), New York (25.4\%), Florida (22.7\%), Nevada (21.63\%), and Hawaii (20.7\%). Clearly, the immigrant population has increased in the United States overall, and in some states the increase in the immigrant population has been substantial. As a result, immigration has become a highly salient issue for the American public.

Large scale immigration has led to social, political, and economic changes in American life that have drawn considerable attention from scholars. One important question is how immigration has influenced 
Figure 1. Trend in percentage foreign born in the United States, 1850-2010

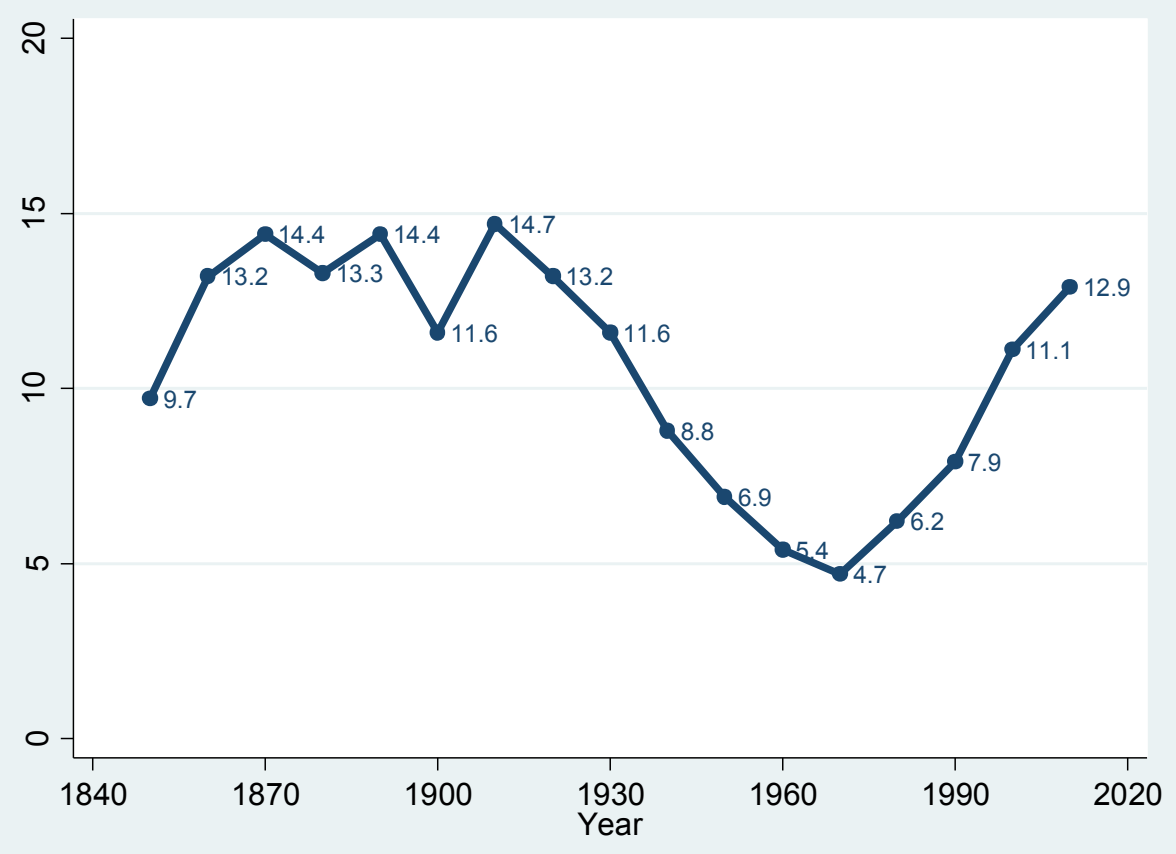

Source: U.S. Census, decennial censuses, 1900 to 2000; American Community Survey, 2010. 
Table 1: Change of Percentage of foreign-born population, 1996-2008

\begin{tabular}{lrrrlrrr|}
\hline State & $\mathbf{1 9 9 6}$ & $\mathbf{2 0 0 8}$ & \%Increase & State & $\mathbf{1 9 9 6}$ & $\mathbf{2 0 0 8}$ & \%Increase \\
\hline Alabama & $1.73 \%$ & $4.06 \%$ & $134.68 \%$ & Montana & $1.94 \%$ & $1.71 \%$ & $-11.83 \%$ \\
\hline Alaska & $4.75 \%$ & $7.31 \%$ & $53.92 \%$ & Nebraska & $3.76 \%$ & $7.29 \%$ & $94.14 \%$ \\
\hline Arizona & $14.91 \%$ & $17.42 \%$ & $16.87 \%$ & Nevada & $13.66 \%$ & $21.63 \%$ & $58.33 \%$ \\
\hline Arkansas & $1.93 \%$ & $4.58 \%$ & $136.97 \%$ & New Hampshire & $3.95 \%$ & $5.91 \%$ & $49.45 \%$ \\
\hline California & $29.96 \%$ & $33.52 \%$ & $11.88 \%$ & New Jersey & $17.41 \%$ & $25.86 \%$ & $48.56 \%$ \\
\hline Colorado & $7.19 \%$ & $12.00 \%$ & $66.89 \%$ & New Mexico & $13.66 \%$ & $11.31 \%$ & $-17.23 \%$ \\
\hline Connecticut & $11.01 \%$ & $15.19 \%$ & $37.90 \%$ & New York & $21.93 \%$ & $25.42 \%$ & $15.93 \%$ \\
\hline Delaware & $5.23 \%$ & $12.77 \%$ & $144.32 \%$ & North Carolina & $4.02 \%$ & $7.79 \%$ & $93.78 \%$ \\
\hline Florida & $17.33 \%$ & $22.65 \%$ & $30.68 \%$ & North Dakota & $1.47 \%$ & $2.20 \%$ & $48.99 \%$ \\
\hline Georgia & $3.80 \%$ & $11.78 \%$ & $209.63 \%$ & Ohio & $2.90 \%$ & $4.20 \%$ & $44.82 \%$ \\
\hline Hawaii & $20.48 \%$ & $20.70 \%$ & $1.06 \%$ & Oklahoma & $2.36 \%$ & $4.89 \%$ & $107.48 \%$ \\
\hline Idaho & $4.56 \%$ & $6.06 \%$ & $33.09 \%$ & Oregon & $8.52 \%$ & $9.71 \%$ & $13.97 \%$ \\
\hline Illinois & $10.76 \%$ & $15.77 \%$ & $46.53 \%$ & Pennsylvania & $4.45 \%$ & $5.42 \%$ & $21.78 \%$ \\
\hline Indiana & $2.49 \%$ & $4.24 \%$ & $69.85 \%$ & Rhode Island & $12.43 \%$ & $14.34 \%$ & $15.31 \%$ \\
\hline lowa & $2.63 \%$ & $6.09 \%$ & $132.02 \%$ & South Carolina & $1.59 \%$ & $4.26 \%$ & $167.51 \%$ \\
\hline Kansas & $4.83 \%$ & $6.46 \%$ & $33.88 \%$ & South Dakota & $1.67 \%$ & $3.43 \%$ & $105.12 \%$ \\
\hline Kentucky & $1.04 \%$ & $3.64 \%$ & $250.63 \%$ & Tennessee & $1.72 \%$ & $5.29 \%$ & $206.93 \%$ \\
\hline Louisiana & $2.23 \%$ & $3.76 \%$ & $68.28 \%$ & Texas & $13.79 \%$ & $19.56 \%$ & $41.83 \%$ \\
\hline Maine & $3.52 \%$ & $3.10 \%$ & $-11.87 \%$ & Utah & $6.89 \%$ & $9.98 \%$ & $44.98 \%$ \\
\hline Maryland & $8.83 \%$ & $16.72 \%$ & $89.43 \%$ & Vermont & $3.76 \%$ & $3.97 \%$ & $5.51 \%$ \\
\hline Massachusetts & $12.16 \%$ & $16.34 \%$ & $34.42 \%$ & Virginia & $6.88 \%$ & $12.87 \%$ & $87.13 \%$ \\
\hline Michigan & $6.00 \%$ & $7.85 \%$ & $30.94 \%$ & Washington & $8.01 \%$ & $13.72 \%$ & $71.16 \%$ \\
\hline Minnesota & $4.63 \%$ & $7.95 \%$ & $71.78 \%$ & West Virginia & $1.02 \%$ & $1.10 \%$ & $7.76 \%$ \\
\hline Mississippi & $1.58 \%$ & $2.88 \%$ & $82.12 \%$ & Wisconsin & $3.47 \%$ & $5.87 \%$ & $69.37 \%$ \\
\hline Missouri & $2.20 \%$ & $4.02 \%$ & $82.78 \%$ & Wyoming & $2.20 \%$ & $2.91 \%$ & $32.16 \%$ \\
\hline & & & & & & & \\
\hline
\end{tabular}

Data source: Current Population Survey, U.S. Census Bureau, various years 
the evolution of the American welfare system. On its face, the immigrant population in the United States has a number of characteristics that would make many immigrants prime candidates for participation in various facets of the American welfare state. According to his analysis of data from the 2010 and 2011 Current Population Survey (CPS), Camarota (2012) finds that immigrants are substantially more likely to have less than a high-school degree than native-born Americans ( $28.1 \%$ to $7.2 \%)$, and immigrants are less likely to have completed some college $(16.9 \%$ to $29.8 \%)$ or have a college degree (29.0\% to $32.8 \%$ ) than native-born Americans. Immigrants have lower median incomes than native-born Americans $(\$ 34,021$ to $\$ 43,701)$, as well as lower median incomes per household member $(\$ 13,930$ to $\$ 20,955)$. Further, immigrants are more likely to be in poverty $(19.9 \%$ to $13.5 \%)$, and by a margin of 43.6\% to $31.1 \%$ immigrants are more likely than native-born Americans to live in "near" poverty (i.e., under $200 \%$ of the poverty threshold for a given family size). According to CPS data from 2011, immigrants are more likely to be without health insurance $(34.1 \%$ to $13.8 \%)$ and are less likely to be home owners (51.8\% to $68.5 \%)$.

These characteristics fit the profile of the welfare-active population and appear to translate into a greater likelihood that immigrants will be involved in the American welfare system, since similarlysituated native-born Americans would likely be relatively high participants in welfare programs. There is some evidence that immigrants are more likely than non-immigrants to participate in the welfare system. Using CPS data from 2010 and 2011, Camarota (2012) finds that immigrants are more likely than native-born Americans to receive funds from two broad sets of programs: (1) food assistance, such as Supplemental Nutrition Assistance Program (SNAP, aka food stamps) and free and reduced lunch (24.1\% to $13.9 \%)$; and (2) Medicaid (28.4\% to $17.5 \%)$. Immigrants and native-born Americans are roughly equally likely to receive funds from two other categories of programs: (1) cash assistance programs, such as Temporary Assistance for Needy Families (TANF), Supplemental Security Income (SSI), and state general assistance (5.8\% for immigrants, 5.4\% for native-born Americans); and (2) subsidized housing 
(4.6\% to $4.3 \%) .{ }^{1}$ Overall, an estimated $36.3 \%$ of immigrants are participants in at least one of these governmental assistance programs, compared to approximately $22.8 \%$ of non-immigrants.

Given the relative socioeconomic status and the relatively higher program participation rates for immigrants, it would not be surprising if Americans' attitudes toward the welfare state were influenced, at least in part, by their attitudes toward immigrants, immigration, and changes in the foreign-born composition of the American population. Immigration is a divisive issue in the United States, and there are many Americans who disagree about the degree to which immigration should be expanded, reduced, or kept the same. Further, Americans disagree sharply over immigration policy (e.g., path to citizenship, deportation of illegal immigrants, guest worker program), as well as the degree to which immigrants - particularly those who are not citizens and/or who are in the United States without documentation and legal status-should be eligible for government goods and services in the same way that native-born Americans should be. Finally, there is some evidence-primarily from Western European countries - that increased population diversity of the sort associated with greater immigration has the effect of changing how individuals think about welfare policies and the degree to which individuals support anti-poverty and redistributive policies (Eger 2010; Larsen 2011; Mau and Burkhardt 2009; Senik, et al. 2009; Bay and Pedersen 2006). We suggest that the possible connection between how Americans think about the welfare state and welfare programs, on one hand, and how Americans think about immigration and immigrants, on the other hand, is an important and potentially-fruitful topic for study.

\section{PREVIOUS RESEARCH: WHAT DO WE KNOW?}

The relationship between race and the American welfare state has a long and well-documented history. Historical accounts of the initial construction of the welfare state argue that race played a major role in its design (Brown 1999; Liberman 1998; Noble 1997; Handler 1995). In addition, a number of quantitative analyses find links between minority caseload and welfare expenditures, measured as 
overall spending and/or monthly cash benefits (Howard 1999; Orr 1976; Plotnick and Winters 1985; Wright 1976). Moreover, a great deal of research has examined how attitudes toward racial minorities and stereotypes affect opinions on welfare (Gilens 2000; Johnson, 2003; Jacoby 1994; Nelson 1999; Peffley, Hurwitz, and Schneiderman 1997; Soss, Fording, and Schram 2011).

The work of Martin Gilens (2000) is an important starting point in understanding how attitudes toward immigration can be related to attitudes toward welfare, even though his research was not about immigration. Gilens offers the provocative hypothesis that how Americans think about blacks has a strong effect on how Americans think about welfare, and in his empirical analyses he finds strong support for this assertion. The argument is that welfare policy is highly racialized, in the sense that Americans perceive African Americans as being disproportionately likely to be recipients of welfare policies; this connection prompts Americans to link their attitudes toward blacks with their attitudes toward welfare. Obviously, Gilens' work is about racial attitudes and support for welfare, and our work is about the effect of immigration attitudes on support for welfare. However, it is not difficult to draw parallels between Gilens' arguments and the linkage between attitudes toward immigrants and public support for welfare. If, for instance, immigrants are over-represented among the ranks of welfare recipients, it is not implausible to argue that Americans might have shifted their attention from African Americans to immigrants when they assess their welfare attitudes, precisely because of a similar fear that immigrants might absorb welfare resources.

Empirical research conducted in western developed countries--especially in Europe--shows some support for the argument that either the presence of immigrants in one's context or individuals' subjective attitudes toward immigrants can influence public support for welfare (Burgoon, Koster, and van Egmond, 2010; Eger 2010; Hjerm and Schnabel 2012; Larsen 2011; Mau and Burkhardt 2009; Sumino 2013). Specifically, increased immigration has the effect of increasing the racial and ethnic heterogeneity of a given political system, and this might reduce the sense of national identity and social 
solidarity needed for the welfare state. Individuals in homogenous societies are likely to support the welfare system because welfare benefits go to people who they consider to be like themselves. The influx of immigrants, however, creates a sense of "us" and "them" and therefore shatters the sense of a common national identity and severely reduces social solidarity. As a result, public support for the welfare system may dwindle because recipients of welfare programs now include members of the immigrant "out-group," who are deemed as less worthy of receiving public goods. Such processes may be in place even in countries such as Sweden (Eger 2010) and Denmark (Larsen 2011) known for their generous system of welfare benefits.

Scholars have long associated high racial heterogeneity with low support for social welfare in a society (Miguel and Gugerty, 2005; Miguel 1999; Hero and Preuhs 2007; Habyarimana et al. 2007; Gilens 2003; Soss, Schram, Vartanian, and O'Brien, 2001; Banting and Kymlicka 2005; Wolfe and Klausen 1997). One consequence of increasing immigration rates over the past several decades is increasing racial, ethnic, or nationality heterogeneity, particularly as immigrant populations disperse beyond the typical gateway states. In addition, immigrants are shown to consume more welfare benefits than native citizens in the United States both before and after the 1996 welfare reform (Hanson 2004: 10; Camarota 2012). What is missing from much of the extant research on support for the American welfare state is an explicit consideration of how individuals' attitudes toward immigrants and immigration affect support for the welfare state in the American context. If immigrants are overrepresented among the ranks of welfare recipients, and if immigration-driven heterogeneity influences how Americans think about welfare, we would expect that Americans would link their evaluations of immigration and immigrants to their evaluations of various aspects of the welfare state, including evaluations of welfare recipients and preferences for spending on welfare programs. 


\section{IMMIGRATION AND WELFARE PREFERENCES}

Why should attitudes toward immigration have an effect on how Americans evaluate the welfare state? We suggest that there are at least three processes that could result in a linkage between individuals' attitudes about immigrants and immigration, on one hand, and attitudes toward welfare programs and the recipients of those programs, on the other.

\section{Welfare participation rates among immigrants}

First, this relationship may be tied to the fact that immigrants are more likely to be beneficiaries of the welfare system. In this scenario there is a connection based on the greater representation of immigrants as recipients of welfare programs and a resulting perception on the part of Americans that immigrants are more likely to be part of the welfare system. If this describes the process, we would expect Americans to connect their attitudes toward immigrants and their attitudes toward welfare because they would perceive welfare programs to be "immigrationized," in much the same way that Gilens describes welfare spending as "racialized." The "immigratization" of welfare programs in the minds of Americans could result in a strong connection between Americans evaluations of immigration and immigrants, on one hand, and their evaluations of the welfare state, on the other.

Of course, it is possible for Americans to perceive inaccurately that immigrants are part of the welfare system when, in fact, they are equally or less likely to be participants in welfare programs. In the United States, there indeed does appear to be an overrepresentation of immigrants among the ranks of those in poverty and in the welfare system. Immigrants living in the United States (and their U.S.-born children) are more likely to be living in poverty than native-born Americans, by a margin of $23.3 \%$ to $13.5 \%$ (Camarota, 2012). While immigrants are roughly equally likely to receive cash assistance and housing subsidies as nonimmigrants, they are more likely to receive food assistance and be recipients of Medicaid, and overall they are more likely (by a margin of $36.3 \%$ to $22.8 \%$ ) to receive "any welfare" than non-immigrants. Moreover, immigrants are significantly more likely to be eligible for the Earned Income Tax Credit (EITC) and the 
Additional Child Tax Credit (ACTC). For immigrants, $29.7 \%$ are eligible for the EITC, compared to only $14.5 \%$ of non-immigrants, though this program requires recipients to present a Social Security card; the ACTC program does not require a Social Security card, and according to data from the CPS $20.6 \%$ of immigrants are eligible compared to only $8.4 \%$ of non-immigrants (Camarota, 2012). ${ }^{2}$ All in all, it would appear that immigrants are more likely to be part of the broad panoply of programs falling under the umbrella of the "welfare state," and this may contribute to Americans' perceptions that immigrants are part of the welfare system. This, in turn, can contribute to the connection between Americans' attitudes toward immigration and their attitudes toward the welfare state.

\section{Immigrant stereotypes}

A second possible source of the connection between Americans' immigration attitudes and their welfare attitudes is stereotypes toward immigrants. How Americans think about immigrants can have an empirical component to it, but Americans may extend broad descriptive attributes of immigrants in general toward specific groups of immigrants or individual immigrants. For instance, while immigrants may be more likely than non-immigrants to be participants in the welfare system, some Americans may inaccurately perceive that a majority of welfare recipients are immigrants or else paint all or most immigrants with the broad brush of being participants in the welfare system.

Further, some Americans may have stereotypes about immigrant groups that affect their evaluations of immigrants and, hence, their perceptions of how deserving immigrants are of receiving welfare benefits. Research examining stereotypes of the generic immigrant find remarkably consistent results across countries; the dominant stereotype of immigrants is that they are incompetent and untrustworthy (Cuddy, Fiske, Demoulin, and Leyens 2000; Cuddy et al. 2009, Lee and Fiske 2006). According to the stereotype content model, individuals attribute competence to those who they identify as economically self-reliant or successful and holding a prestigious job, whereas warmth or trustworthiness is afforded to those perceived to be harmless or unable to compete with the in-group 
for things like jobs, power, and resources (Fiske et al. 2002; Fiske et al. 1999). This prevailing stereotype of the incompetent and untrustworthy immigrant is for some Americans the "go-to" image for the generic immigrant. According to work by Lee and Fiske (2006), individuals must be given additional information in order to move beyond the generic immigrant and call forth stereotypes that differ across various immigrant groups. In other words, the stereotype content model predicts that perceptions of immigrants will vary only when individuals are given additional information, such as nation of origin associated with the immigrant.

If the generic immigrant is seen by some or many Americans as incompetent and untrustworthy, can that be linked to perceptions of welfare deservedness? In fact, scholars have examined the rank ordering of deservingness among welfare recipients and find that immigrants are indeed perceived to be the least deserving (van Oorschot, 2006). Among all welfare recipient groups, elderly people are seen as the most deserving, followed by sick and disabled people, and unemployed people, with immigrants deemed to be the least deserving. This pattern is universal across men and women, individuals with different ages, education, and income levels, and even across cultures and societies (van Oorschot, 2006; van Oorschot, 1998; Appelbaum, 2002). These stereotypical images of immigrants could possibly contribute to the linkage between Americans' attitudes toward immigration and their attitudes toward the welfare state.

\section{Immigrant-driven diversity}

Alternatively, the relationship between immigration attitudes and welfare attitudes could be due to the higher racial and ethnic diversity that immigration brings and a resulting sense that individuals who may be different in values, culture, behavior, or appearance are the beneficiaries of government programs. In homogenous societies, supporting an expanded welfare state is seen as a means of helping individuals who are "like us" but who have perhaps run into a rough spell requiring government assistance. As the diversity of a society increases, individuals are called upon to support welfare programs for others who are not similar to themselves. In this scenario, immigrants are people who may be seen as violating standards 
of behavior that were developed in the past within a homogenous society, and in the context of higher diversity and perceived violations of behavioral norms immigrants may be seen as not being equally deserving of government help. The result will be a strong connection between how individuals evaluate immigrants and the level of support for the welfare state.

The bulk of the research in the American states clearly links increasing racial heterogeneity (i.e. increasing black populations) with declining support for welfare programs (Miguel and Gugerty, 2005; Miguel 1999; Hero and Preuhs 2007; Habyarimana et al. 2007; Gilens 2003; Soss, Schram, Vartanian, and O'Brien, 2001; Banting and Kymlicka 2005; Wolfe and Klausen 1997). Using the American experience with race and welfare as a foundation, comparative scholars have begun to examine whether or not the increasing immigrant populations experienced by Europe during the 1990s and 2000s might lead to an erosion of support for welfare programs (Burgoon, Koster, and van Egmond, 2010; Eger 2010; Hjerm and Schnabel 2012; Larsen 2011; Mau and Burkhardt 2009; Sumino 2013). According to Kymlicka and Banting $(2006,286)$ this position has even become dominant: "[T]he strongly racialized dimension of US welfare politics is no longer seen as an anomaly...but rather as a normal, even inevitable, reaction to the simple fact of ethnic heterogeneity. Indeed, the United States has come to represent the leading international example of the proposition that heterogeneity as such erodes redistribution."

Scholars in comparative politics tend to use racial heterogeneity and ethnic heterogeneity interchangeably. It could be argued that in the American case such conflation is inappropriate. Prior to the debate and passage of the Personal Responsibility Work Opportunity Reconciliation Act (PWORA) in 1996, there is little evidence to suggest a relationship between ethnic heterogeneity and welfare attitudes. Under the Aid to Families with Dependent Children (AFCD) program, states such as New York and California that contained the country's largest ethnic populations also provided generous welfare programs. The debate over PRWORA in the early 1990s and the systematic exclusion of immigrations from social safety net programs offers a hint that the relationship between ethnicity and support for 
welfare might be changing in America. The unveiling of the Republican Contract with America in 1994 formalized political plans for saving federal dollars through denying noncitizens access to programs; moreover, the bipartisan support for PRWORA for these restrictions was striking (Singer 2004). In addition, even states with generous welfare benefits and large ethnic populations appear to have "embraced the prevailing anti-immigrant rhetoric" (Singer 2004:26) For example, Hero (2010: 462) argues that the series of anti-immigrant propositions passed in California during the early 1990s reflect "stirred white resentments toward general egalitarian social policies and programs as well as programs designed specifically for ethnoracial minorities." Interestingly, the expected contraction of welfare generosity associated with increased ethnic heterogeneity, similar to the contraction of welfare generosity in response to increases in racial heterogeneity, might be muted in some instances. For example, under TANF block grants for cash assistance, job training, and the like, states are subject to maintenance of effort requirements that require states to maintain spending levels at a certain level that might mute the expected contraction of generosity. Regardless of whether public opinion affects policy outcomes, the contention that increased ethnic heterogeneity might be associated with decreased support for welfare rests on the idea that the most recent wave of immigration to the U.S. looks remarkably different than previous waves. Prior waves of immigration were dominated by European immigrants, while today four out of every five foreign-born individuals entering the U.S. are from Asia, Africa, the Carribbean, Latin America or the Middle East (Hero 2010).

In summary, we hypothesize that an individual's attitude towards immigrants plays a substantial role in contemporary support for the American welfare state. This may be due to welfare utilization rates by immigrants, stereotypes of immigrants as incompetent, untrustworthy, and undeserving, or immigrant-driven racial and ethnic diversity. Regardless of the causal mechanism, the hypothesized relationship remains the same: positive (negative) attitudes toward immigrants and immigration correspond to increasing (decreasing) support for welfare. 


\section{DATA AND METHODS}

In order to estimate the relationship between attitudes toward immigration (i.e., attitudes toward legal immigration and toward illegal immigrants) and attitudes toward welfare (i.e., attitudes toward welfare recipients and spending on welfare), we rely on data from the Cumulative American National Election Study (CANES) surveys from 1992 to 2012. Survey items have been included in the ANES surveys about affect toward welfare recipients since the 1970s, but questions about immigration and welfare spending are a more recent addition. We use 1992 as the starting point for our study to encompass years that include variables representing welfare and immigration attitudes, as well as a range of relevant control variables.

We use two variables as dependent variables in our models. First, we utilize data on individuals' affect toward welfare recipients by including a feeling thermometer for welfare recipients, coded 0 for those with strong negative affect, 50 representing the neutral position, and 100 for those with strong positive affect. This variable captures the degree to which individuals have positive or negative feelings toward welfare recipients. Second, we use as a dependent variable an ordinal measure of support for welfare spending, coded 1 for respondents who support increases in welfare spending, 0 for those who would like to keep welfare spending at current levels, and -1 for those who prefer decreases in welfare spending.

We include in our models a set of core independent variables that reflect individuals' attitudes toward immigrants. First, in five surveys (i.e., 1992, 1994, 2004, 2008, and 2012) the ANES includes a feeling thermometer item for illegal immigrants; here again, this variable ranges from 0 (negative affect) to 100 (positive affect). If attitudes toward illegal immigrants are related to welfare attitudes, we would expect the coefficient for this variable to be positive. This would indicate that individuals who hold a positive view toward illegal immigrants would be more supportive of welfare programs; conversely, of course, this would also indicate that individuals who hold negative views toward illegal immigrants would be less supportive of welfare programs. Second, in seven surveys (i.e., 1992, 1994, 1996, 2000, 2004, 2008, and 
2012) the ANES includes items relating to the degree to which individuals support increases in immigration. This variable is coded 1 for respondents who support increased immigration, -1 for respondents who support decreased immigration, and 0 for those who prefer keeping current levels of immigration. The careful reader will note that no mention is made in this question to "illegal" immigration, so this item can plausibly be thought of as reflecting respondents' preferences for general levels of immigration. Here again, we expect the coefficient for this variable to be positive. Third, we also use principal components factor analysis to create a scale of immigration attitudes based on these two immigration items. These two variables load strongly on a single factor representing individuals' general immigration attitudes (eigenvalue $=1.339$, variance explained $=0.670$ ). Because values on both variables are necessary to create this factor score, we can use this global measure of immigration attitudes only for the years 1992, 1994, 2004, 2008, and 2012.

We also include in our model several other variables that could be related to welfare attitudes. First, Gilens demonstrates that attitudes toward welfare spending are influenced by individuals' attitudes toward blacks, so we include in our models a feeling thermometer variable for blacks. Moreover, because welfare programs are designed for low-income individuals in American society, we include a variable for affect toward the poor, measured using the traditional feeling thermometer scale. We hypothesize that the coefficients for each of these variables will be positive, indicating that individuals who hold favorable attitudes toward blacks and the poor should be more supportive of welfare. Second, individuals' attitudes toward welfare programs are likely to reflect how they evaluate the role of government in our society. These evaluations are reflected in partisan attachments and ideological orientations, so we include two variables: (1) a seven-point partisan identification scale, ranging from 0 (strong Democrat) to 6 (strong Republican); and (2) political ideology, measured on a seven-point scale ranging from 0 (strong liberal) to 6 (strong conservative). We expect the coefficients for each variable to be negative, suggesting that Republicans and conservatives will be the least favorable in their attitudes toward welfare. Finally, we 
include in our models a series of demographic variables, including separate variables for black, Hispanic, and Asian respondents, age, gender, education, family income, and church attendance. We hypothesize that blacks, Hispanics, Asians, and women are more supportive of welfare recipients and welfare spending than other individuals. We also suggest that older and high-income individuals will be less favorably oriented toward welfare, while those who are high in church attendance will be more supportive of welfare. Finally, in order to capture fluctuations in welfare attitudes that may vary systematically over time and across states, we include fixed effects variables for each year and each state. In particular, the state fixed effects variables capture the effects of state characteristics-e.g., state welfare policies, demographic attributes - that could affect the relationship between immigration attitudes and welfare attitudes.

A description of the variables included in the model assessing the relationship between attitudes toward immigrants and attitudes towards welfare can be found in Appendix I.

\section{EMPIRICAL RESULTS}

\section{Affect toward welfare recipients}

In Table 2 we report the OLS regression coefficients for three models of affect toward welfare recipients. Model (1) uses the pro-immigration factor score as the primary independent variable and is based on five election years (since both of the component variables comprising the scale are available only in 1992, 1994, 2004, 2008, and 2012). In Model (2) we separate out the two component variables comprising the pro-immigration scale; this permits us to provide separate estimates of the effects of affect toward illegal immigrants and support for immigration on support for welfare recipients. Finally, in Model (3) we drop the illegal immigrants feeling thermometer, and this permits us to estimate the model for seven elections years. We estimate the third model to take advantage of the opportunity to estimate the model with a larger sample size and to cover more election years.

As one can see, immigration attitudes have a powerful effect on individuals' attitudes toward welfare recipients. In Model (1) the coefficient for the pro-immigration factor score is positive and highly 
Table 2. OLS estimates for models of affect toward welfare recipients, selected years (1992-2012), Cumulative American National Election Study

(1)

Variable

Pro-Immigration factor score [+]

Feeling thermometer: illegal immigrants [+]

Support for immigration [+]

Feeling thermometer: blacks [+]

Feeling thermometer: the poor $[+]$

Partisan identification [-]

Political ideology [-]

Female respondent $[+]$

Black respondent $[+]$

Hispanic respondent $[+]$

Asian respondent [+]

Age [-]

$\operatorname{Age}^{2}[+]$

Education [+]

Family income [-]

Church attendance [+]

Survey year: 1994

Survey year: 1996

Survey year: 2000

Survey year: 2004

Survey year: 2008

Survey year: 2012
(2)

(3)

b $\quad t$

b $\quad$ t

b t

$\begin{array}{cc}4.744 & 18.07^{* * *} \\ --- & --- \\ --- & -- \\ 0.129 & 6.32^{* * *} \\ 0.390 & 20.68^{* * *} \\ & \\ -0.803 & -5.35^{* * *} \\ -0.726 & -4.55^{* * *} \\ 0.758 & 1.88^{*} \\ 2.523 & 2.95^{* *} \\ -2.500 & -3.18^{* *} \\ 0.966 & 0.46 \\ -0.199 & -2.29 * \\ 0.002 & 2.90^{* *} \\ 0.381 & 1.55 \\ -1.564 & -5.89 * * * \\ 0.242 & 1.88^{*} \\ & \\ -3.225 & -5.03^{* * *} \\ --- & --- \\ --- & --- \\ 1.383 & 1.40 \\ 0.225 & 0.35 \\ -2.517 & -3.88^{* * *} \\ & \end{array}$

---
0.182
2.018
0.113
0.384
-0.735
-0.664
0.541
2.371
-3.302
1.151
-0.213
0.003
0.434
-1.507
0.216

-3.495
---
---
1.264
0.356
-2.451

---
$13.38^{* * *}$
$6.48^{* * *}$
$5.41^{* * *}$
$19.89^{* * *}$

$-4.98^{* * *}$
$-4.11^{* * *}$
1.41
$2.89^{* *}$
$-4.15^{* * *}$
0.55
$-2.46 * *$
$3.06 * *$
$1.76 *$
$-5.82 * * *$
$1.65 *$
$-5.72 * * *$
---
---
1.30
0.57
$-3.87^{* * *}$

$---$

$--$

3.728

0.171

0.388

$---$

$13.61^{* * *}$

$8.63 * * *$

$23.63 * * *$

$-0.994$

$-0.950$

0.417

2.789

$-0.437$

0.737

$-0.189$

0.002

0.709

$-1.620$

0.403

$-6.62 * * *$

$-6.24 * * *$

1.03

$3.18^{* *}$

$-0.64$

0.40

$-2.25 *$

2.92**

$3.11 * *$

$-6.82 * * *$

$2.96 * *$

$-3.464-5.34 * * *$

$0.574 \quad 0.70$

$\begin{array}{ll}-0.629 & -0.47\end{array}$

$1.797 \quad 1.86$

$0.491 \quad 0.82$

$-2.328-3.78^{* * *}$ 
Table 2 (continued)

$\begin{array}{llll}\mathrm{N} & & 9086 & 10578 \\ \mathrm{R}^{2} & 9086 & 0.3620 & 0.324 \\ \mathrm{~F} & 0.355 & 74.44 & 72.04 \\ \text { Prob (F) } & 72.88 & 0.0000\end{array}$

Note: The estimates for Models (1) and (2) are based on data from the 1992, 1994, 2004, 2008, and 2012 CANES surveys; the estimates for Model (3) are based on data from the 1992, 1994, 1996, 2000, 2004, 2008, and 2012 CANES surveys. The baseline (excluded) year comparison group for each model is 1992 . The expected valence of the coefficients is found in brackets following each variable name. For the sake of brevity, coefficients for state fixed effects are not reported. The reported $\mathrm{t}$ statistics are based on standard errors calculated using clustering by state.

$* * *$ prob $<0.001 * *$ prob $<0.01 *$ prob $<0.05$ 
significant $(b=4.744, z=18.07)$. For every one unit increase in pro-immigration attitudes, affect for welfare recipients increases by almost 5 points. Moving across the full range of this variable from the lowest value of -1.49 (representing strong anti-immigration sentiment) to the highest value of 2.63 (representing very positive views toward immigration), we would expect a predicted increase in feeling thermometer scores toward welfare recipients of almost 20 points $(\Delta=4.12 * 4.744=19.55)$. This is a very strong effect of immigration attitudes on attitudes toward welfare recipients and would seem to underscore the connection that Americans are making between immigration and welfare. It is also worth noting that the standardized regression coefficient $(\beta=0.219)$ is the second highest in the model, indicating that this variable is one of the two most powerful predictors of welfare attitudes.

This strong effect of immigration attitudes on attitudes toward welfare recipients is reinforced by the results from Model (2), in which we estimate separately the effects of attitudes toward illegal immigrants and general support for immigration on individuals' attitudes toward welfare recipients. We find that positive attitudes toward illegal immigrants is strongly associated with positive attitudes toward welfare recipients, holding constant the effects of other variables in the model $(b=0.182, t=13.38)$; individuals who give illegal immigrants the most positive evaluations are predicted to score 18.2 points higher on the feeling thermometer scale for welfare recipients than those who give illegal immigrants the most negative evaluations. Moreover, general support for immigration has a strong positive effect on evaluations of welfare recipients $(b=2.018, t=6.48)$; individuals who support increasing immigration give welfare recipients a score on the feeling thermometer that is a bit more than 4 points higher than individuals who prefer decreasing immigration. Note that these two significant effects occur with both variables in the model. Arguably, since we include a measure of attitudes toward illegal immigration in our model, the coefficient for the general immigration variable can be seen as representing to some extent the effect of attitudes toward legal immigration on welfare attitudes. We also note that the illegal immigrants feeling 
thermometer variable has the second highest standardized regression coefficient $(\beta=0.216)$, suggesting that its effect on welfare attitudes surpasses those of almost all other variables in the model.

We can also pick up additional observations by dropping from the model the illegal immigrants feeling thermometer, which is available in the CANES data for only five elections. In Model (3) we estimate the specific effect of general immigration attitudes for seven election surveys and an additional 1,492 observations. Here again, we find that immigration attitudes have strong effects on attitudes toward welfare recipients $(b=3.728, t=13.61)$; this suggests that those who support increased (legal) immigration are predicted to score 7.46 higher on the feeling thermometer for welfare recipients than those who support decreasing immigration. Without controlling for the effects of attitudes toward illegal immigrants, the coefficient for general immigration attitudes almost doubles in magnitude and is free to do more of the heavy lifting in predicting attitudes toward welfare recipients. Although the total effect of this variable on welfare attitudes is not nearly as strong as that for the illegal immigrant feeling thermometer variable in Model (2), it is still quite discernible and reinforces the general finding that immigration attitudes are important determinants of attitudes toward welfare recipients.

We find that across these three models the coefficients for the other variables in the model are generally consistent with expectations. Turning back to the results from Model (1), we find that both affect for blacks $(b=0.129, t=6.32)$ and affect for the poor $(b=0.390, t=20.68)$ have strong effects on attitudes toward welfare recipients that both are in the expected positive direction and well exceed conventional levels of statistical significance. The variable representing attitudes toward the poor has the strongest effect of any variables in the model $(\beta=0.357)$, which is approximately three times the effect of attitudes toward blacks $(\beta=0.126)$. As expected, we also find that partisan identification $(b=-0.803, t=-5.35)$ and political ideology $(b=-0.726, t=-4.55)$ have significant negative effects on attitudes toward welfare recipients, and our findings also point to a strong negative effect of family income $(b=-1.564 ; t=-5.89)$. Regarding the effects of race, our results suggest that black respondents are more positively oriented 
toward welfare recipients $(b=2.523, t=2.95)$, but Hispanic respondents are less favorable and Asian respondents are no different than whites in how they think about welfare recipients. Finally, we find that women and those who regularly attend church services are slightly more favorable in their attitudes toward welfare recipients, but that age has a negative (but nonlinear) effect. Surprisingly, we find little effect of education on attitudes toward welfare recipients in Model (1), though the effect of education reaches statistical significance in Models (2) and (3).

\section{Support for welfare spending}

What about support for welfare spending? In Table 3 we report ordered logit coefficients for three models of support for welfare spending; these models include the same independent variables from Table 2. For Model (1), we again find that the pro-immigration factor score variable has a strong positive effect on support for welfare spending $(b=0.326, t=12.07)$. The strength of this relationship can be demonstrated in Figure 2, in which we plot the predicted probabilities for each of the three outcomes on the dependent variable across different values of the pro-immigration variable, all-the-while holding other variables in the model constant at their means. As one can see, as the pro-immigration variable increases, the probability that individuals support increased or maintained levels of welfare spending increases, while the probability that individuals support decreases in welfare spending decreases as well. For instance, a hypothetical individual who has strong negative immigration attitudes would be much more likely to support decreased welfare spending (predicted probability $=0.532$ ) than an individual with strong positive immigration attitudes (predicted probability $=0.229$ ); an individual who has strong positive immigration attitudes would be most likely to keep welfare spending levels the same (predicted probably $=0.526$ ). The predicted changes in attitudes toward welfare spending along the range of values on pro-immigration scale variable are considerable; indeed, controlling for the effects of other variables in the model, individuals who have the most negative feelings about immigration are a bit over 0.30 more likely to 
Table 3. Ordered logit estimates for models of support for welfare spending, selected years (1992-2012), Cumulative American National Election Study (CANES)

\begin{tabular}{|c|c|c|c|c|c|c|}
\hline \multirow[b]{2}{*}{ Variable } & \multicolumn{2}{|c|}{$(1)$} & \multicolumn{2}{|c|}{$(2)$} & \multicolumn{2}{|c|}{ (3) } \\
\hline & $\mathrm{b}$ & $\mathrm{t}$ & $\mathrm{b}$ & $\mathrm{t}$ & $\mathrm{b}$ & $\mathrm{t}$ \\
\hline Pro-Immigration factor score [+] & 0.326 & $12.07 * * *$ & --- & --- & --- & --- \\
\hline Feeling thermometer: illegal immigrants [+] & --- & --- & 0.009 & $6.35 * * *$ & --- & --- \\
\hline Support for immigration $[+]$ & --- & --- & 0.254 & $6.74 * * *$ & 0.345 & $10.22 * * *$ \\
\hline Feeling thermometer: blacks $[+]$ & -0.002 & -1.01 & -0.002 & -1.13 & 0.001 & 0.49 \\
\hline Feeling thermometer: the poor $[+]$ & 0.014 & $7.44 * * *$ & 0.014 & $7.45 * * *$ & 0.014 & $8.68 * * *$ \\
\hline Partisan identification [-] & -0.145 & $-9.06 * * *$ & -0.144 & $-8.76 * * *$ & -0.156 & $-10.75 * * *$ \\
\hline Political ideology [-] & -0.273 & $-10.99 * * *$ & -0.272 & $-11.10 * * *$ & -0.284 & $-12.55^{* * *}$ \\
\hline Female respondent $[+]$ & 0.218 & $3.47 * * *$ & 0.214 & $3.38 * * *$ & 0.182 & $3.23 * * *$ \\
\hline Black respondent [+] & 0.456 & $5.38 * * *$ & 0.453 & $5.31 * * *$ & 0.430 & $5.32 * * *$ \\
\hline Hispanic respondent [+] & 0.161 & $1.85^{*}$ & 0.147 & $1.66^{*}$ & 0.255 & $3.98 * * *$ \\
\hline Asian respondent [+] & 0.177 & 0.76 & 0.180 & 0.78 & 0.278 & 1.34 \\
\hline Age [-] & 0.001 & 0.10 & 0.001 & 0.06 & 0.001 & 0.07 \\
\hline $\operatorname{Age}^{2}[+]$ & 0.000 & -0.05 & 0.000 & -0.02 & 0.000 & -0.05 \\
\hline Education [+] & -0.064 & $-2.16^{*}$ & -0.063 & $-2.13^{*}$ & -0.056 & -1.95 \\
\hline Family income [-] & -0.270 & $-11.46 * * *$ & -0.269 & $-11.28 * * *$ & -0.260 & $-11.35 * * *$ \\
\hline Church attendance $[+]$ & -0.011 & -0.74 & -0.012 & -0.77 & -0.003 & -0.19 \\
\hline Survey year: 1994 & -0.361 & $-3.47 * * *$ & -0.367 & $-3.57 * * *$ & -0.353 & $-3.56 * * *$ \\
\hline Survey year: 1996 & --- & --- & --- & --- & -0.682 & $-7.37 * * *$ \\
\hline Survey year: 2000 & --- & --- & --- & --- & 0.003 & 0.02 \\
\hline Survey year: 2004 & 0.460 & $3.53 * * *$ & 0.457 & $3.51 * * *$ & 0.499 & $4.08 * * *$ \\
\hline Survey year: 2008 & 0.561 & $4.35^{* * *}$ & 0.563 & $4.36 * * *$ & 0.562 & $4.51 * * *$ \\
\hline Survey year: 2012 & -0.228 & $-2.59 * *$ & -0.227 & $-2.58 * *$ & -0.201 & $-2.31^{*}$ \\
\hline
\end{tabular}


Table 3 (continued)

\begin{tabular}{|c|c|c|c|}
\hline $\mathrm{N}$ & 9069 & 9069 & 10583 \\
\hline Pseudo- $^{2}$ & 0.121 & 0.131 & 0.125 \\
\hline$x^{2}$ & 2411.35 & 2413.67 & 2645.11 \\
\hline $\operatorname{Prob}\left(\chi^{2}\right)$ & 0.0000 & 0.0000 & 0.0000 \\
\hline
\end{tabular}

Note: The estimates for Models (1) and (2) are based on data from the 1992, 1994, 2004, 2008, and 2012 CANES surveys; the estimates for Model (3) are based on data from the 1992, 1994, 1996, 2000, 2004, 2008, and 2012 CANES surveys. The baseline (excluded) year comparison group for each model is 1992. The expected valence of the coefficients is found in brackets following each variable name. For the sake of brevity, coefficients for state fixed effects are not reported. The reported $t$ statistics are based on standard errors calculated using clustering by state.

$* * *$ prob $<0.001 * *$ prob $<0.01 *$ prob $<0.05$ 
Figure 2. Scatterplot of relationship between pro-immigration attitudes and support for greater welfare spending, selected years, (1992-2012), Cumulative American National Election Study

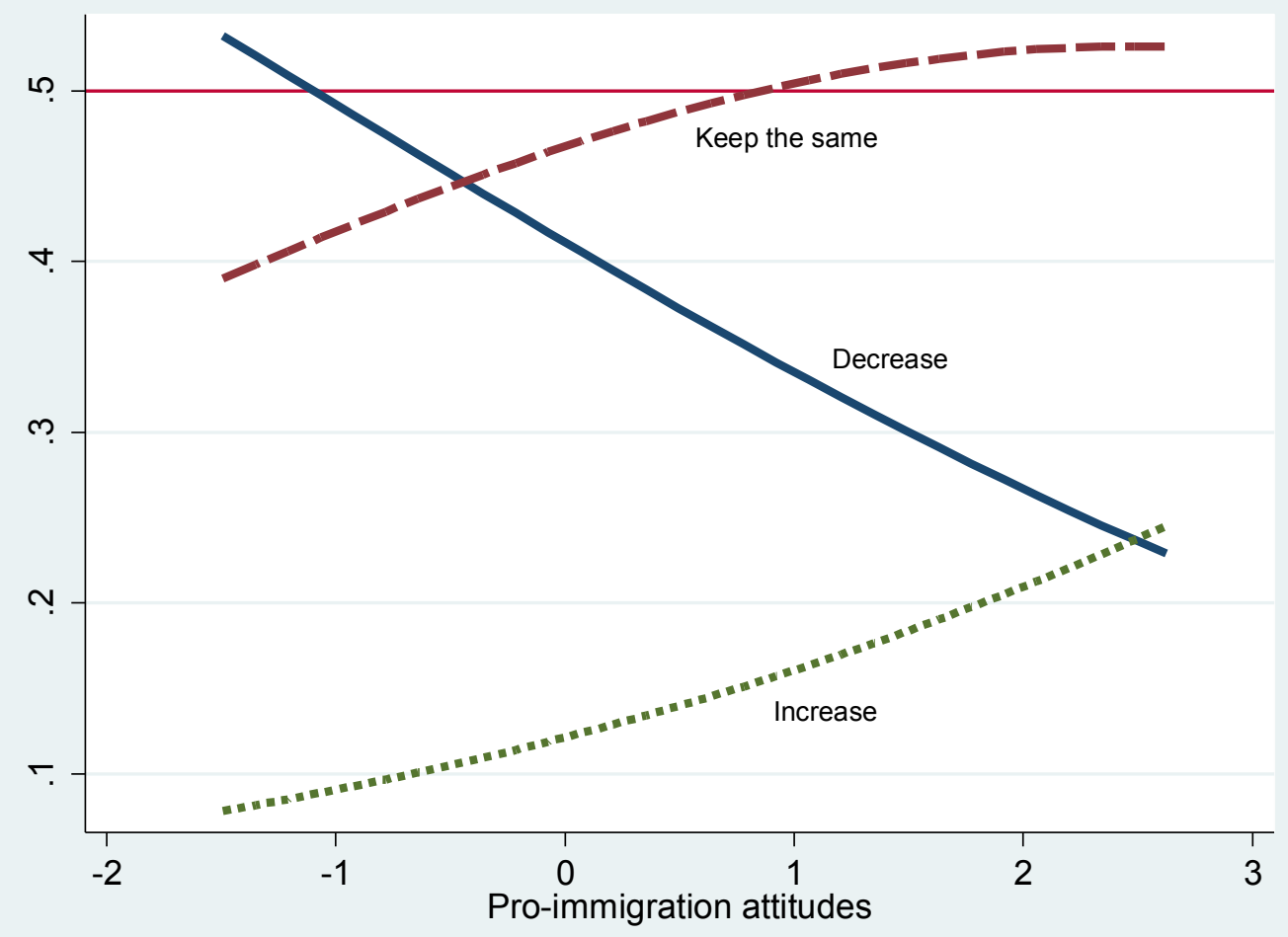


support a decrease in welfare spending than those who have the most positive feelings toward illegal immigrants.

The argument that there is a connection between how Americans think about immigration and how they think about welfare spending is reinforced in our empirical results from Models (2) and (3) in Table 3. Here we explore the separate effects of the component variables comprising the pro-immigration scale by considering the effects of attitudes toward illegal immigrants and general support for expanded immigration on support for welfare spending. In Model (2) we show that attitudes toward illegal immigrants $(b=0.009, t=6.35)$ has a strong positive effect on support for welfare spending. We can plot predicted probabilities for our three values on the dependent variable across values of these two independent variables, holding constant the effects of other independent variables. In Figure 3 we show how support for increased or maintained levels of welfare spending increases as individuals' attitudes toward illegal immigrants shift in the positive direction, while the same shift results in a sharp decrease in individuals' support for decreasing welfare spending. Almost $50 \%$ of individuals with the most negative views toward illegal immigrants are in favor of decreasing welfare spending (predicted probability $=0.496$ ), but this drops by 0.207 (to a predicted probability $=0.289$ ) for those with the most positive views toward illegal immigrants. Further, only $9 \%$ of individuals in the most negative category are predicted to support increased welfare spending. On the other hand, a majority of those with the most positive views toward illegal immigrants are predicted to support keeping welfare spending at current levels (predicted probability $=0.519$ ), and almost $20 \%$ of those in this group are predicted to support an increase (predicted probability $=0.192)$. Clearly, support for illegal immigration has a discernible effect on how Americans think about welfare spending.

We also find that general support for expanded immigration has a strong effect on support for welfare spending, both in conjunction with attitudes toward illegal immigrants in Model $(2)(b=0.254, t=6.74)$ and in a model where the effect is estimated on its own in Model $(3)(b=0.345, t=10.22)$. Clearly, the 
Figure 3. Scatterplot of relationship between affect toward illegal immigrants and support for greater welfare spending, selected years (1992-2004), Cumulative American National Election Study

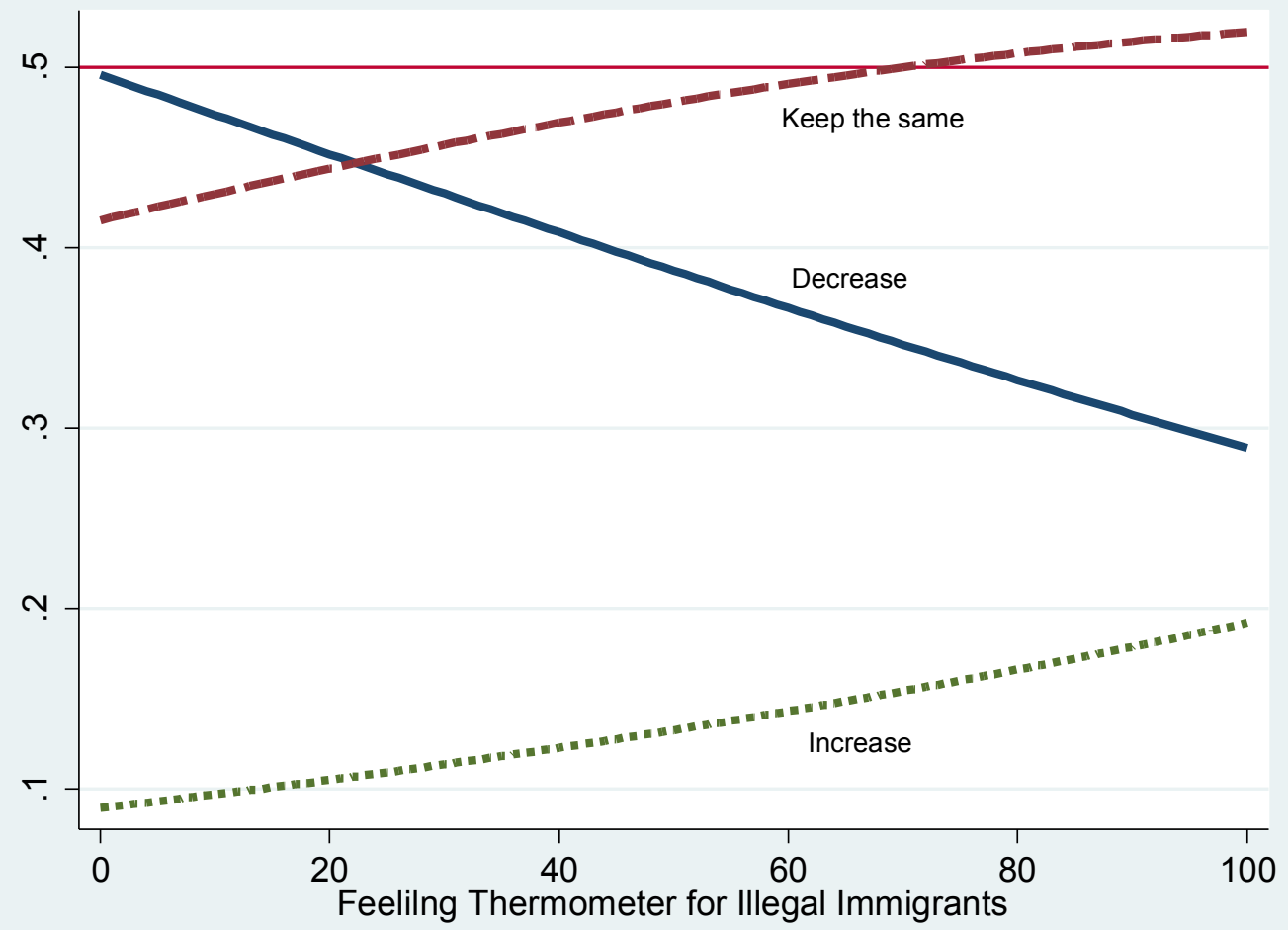


effect of support for expanded immigration is statistically significant, with or without controlling for the effects of attitudes toward illegal immigrants. Using the results from Model (2), in Figure 4 we plot how predicted attitudes toward welfare spending change as individuals shift their attitudes toward increased immigration. Although the coefficient support for expanded immigration is statistically significant, the effect of this variable is somewhat muted in comparison to attitudes toward illegal immigrants. Shifting from preferring decreased immigration to preferring increased immigration lowers preferences for decreased spending on welfare by only about 0.12 (i.e., from 0.451 to 0.331 ), while support for increased spending increases only by 0.058 (i.e., from 0.105 to 0.163 ) and support for keeping welfare spending the same increases by 0.062 (i.e., from 0.444 to 0.506 ). These are discernible, nontrivial effects, but it does represent a smaller effect in comparison to the effect of individuals' attitudes toward illegal immigrants.

What about the effects of other variables in the model? Focusing on the results in Table 3, Model (1), we first find that attitudes toward the poor has a strong positive effect on attitudes toward welfare spending $(b=0.014, t=7.44)$, but the effect of attitudes toward blacks is reduced to statistical nonsignificance $(b=-0.002, t=-1.01)$. As one can see from Figure 5 , the predicted probabilities for the three categories of our welfare spending variable shift very little as one moves from the most negative to the most positive views toward blacks. On the other hand, in Figure 6 we see that shifts in affect toward the poor have important effects on support for increased welfare spending (i.e., predicted probabilities shifting 0.123 , from 0.050 to 0.173 ), keeping welfare spending the same (i.e., 0.217 , from 0.305 to 0.512 ), and decreased welfare spending (i.e., -0.230 , from 0.645 to 0.315 ). These are very large effects that point to the importance of Americans views about the poor in shaping their attitudes toward welfare spending. Finally, many of our control variables behave as expected. Support for welfare spending decreases as a function of partisan identification, political ideology, education, and family income, but welfare spending support is significantly higher among women, blacks, and Hispanics. 
Figure 4. Scatterplot of relationship between support for expanded immigration and support for greater welfare spending, selected years (1992-2004), Cumulative American National Election Study

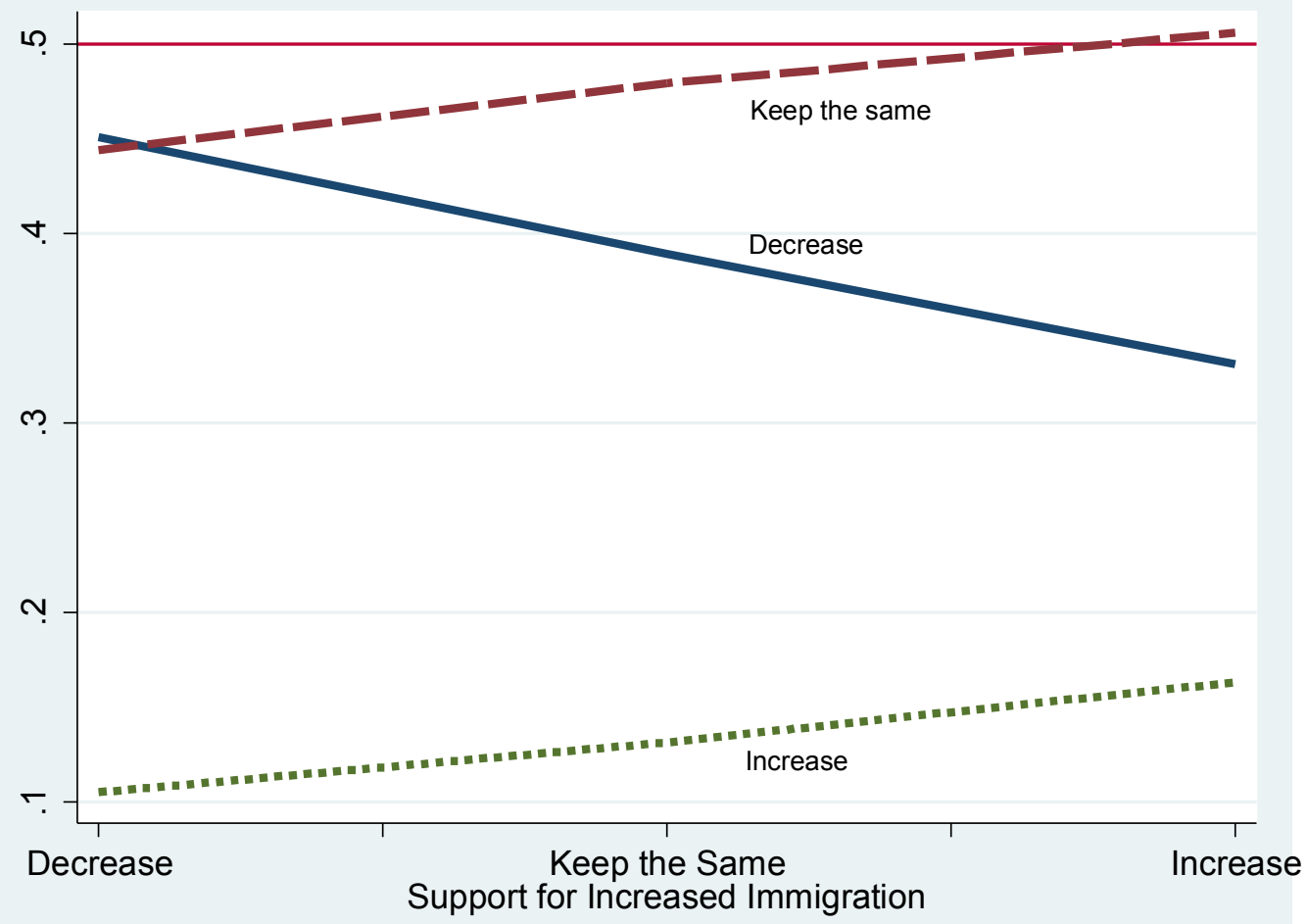


Figure 5. Scatterplot of relationship between affect toward blacks and support for greater welfare spending, selected years (1992-2004), Cumulative American National Election Study

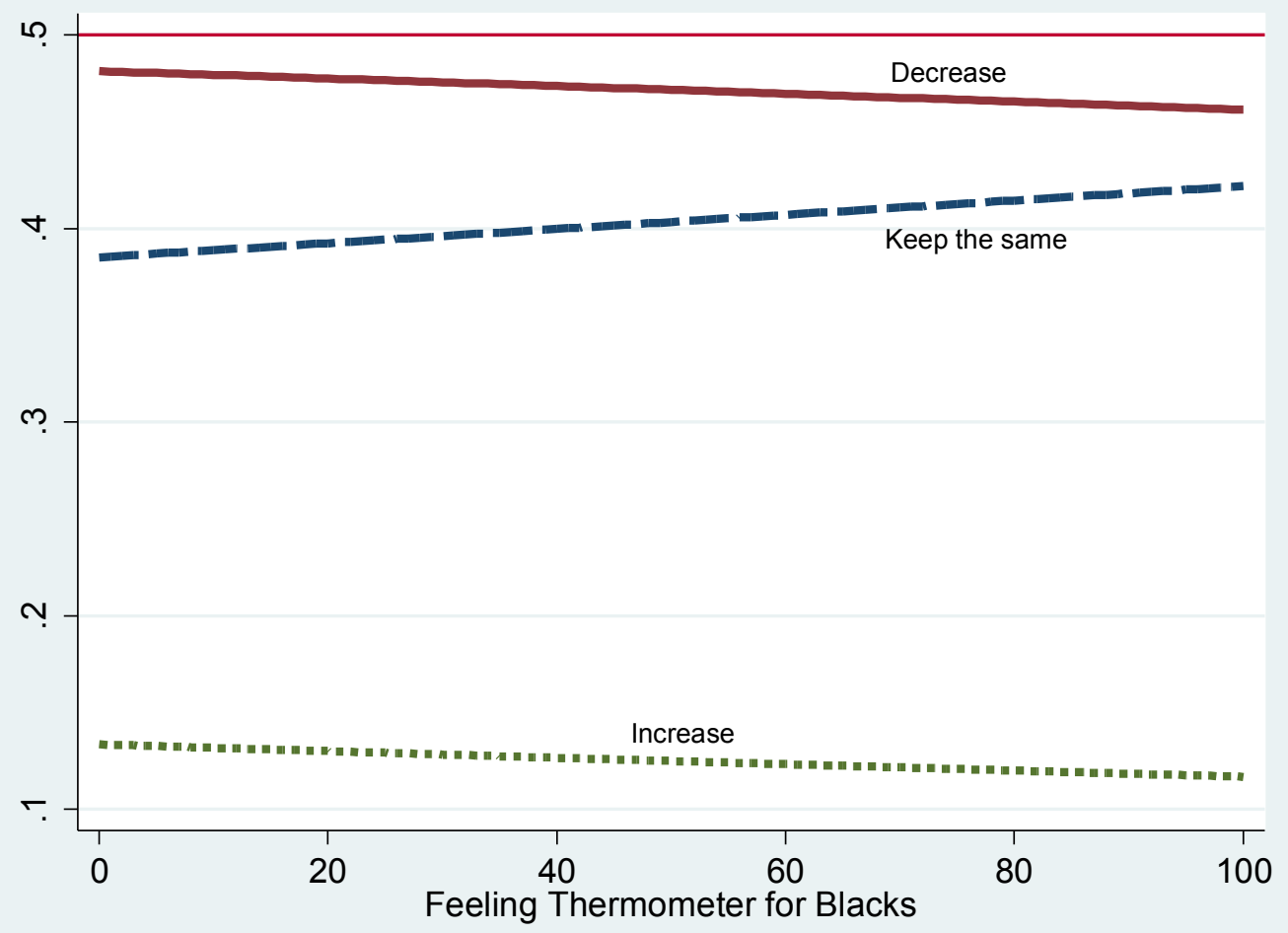


Figure 6. Scatterplot of relationship between affect toward the poor and support for greater welfare spending, selected years (1992-2004), Cumulative American National Election Study

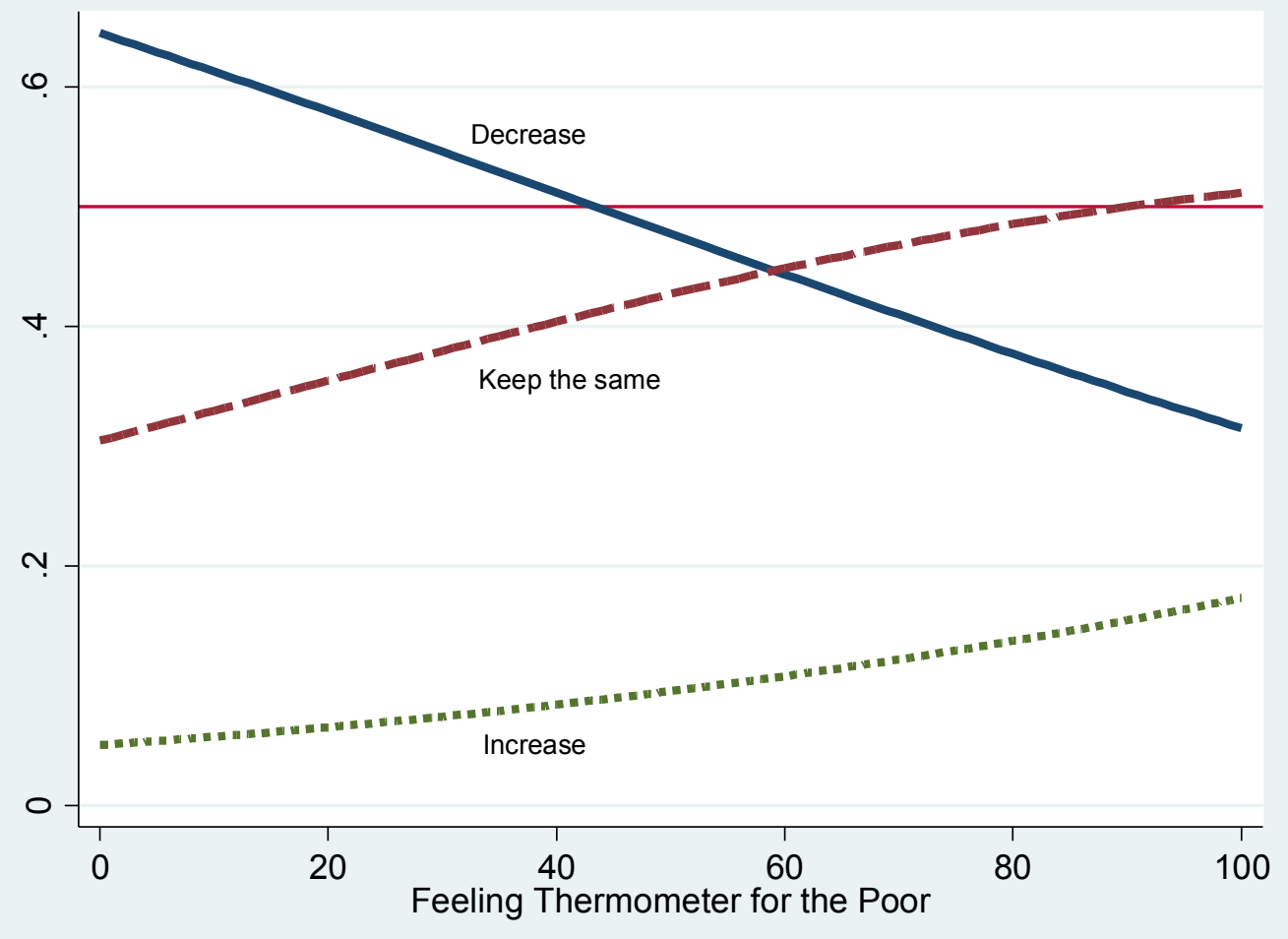


In Appendix 2 we report the results for robustness tests relating to two issues: (1) endogeneity and reciprocal causality issues; and (2) the stability of effects of immigrations attitudes across various groups. Our findings about the relationship between immigration attitudes and support for welfare stand up well in these robustness tests.

\section{SUMMARY AND CONCLUSIONS}

In this paper we explore the relationship between how Americans think about immigration and how they think about the welfare state. Scholars (cf., Gilens, 2000; Alesina, Baqir, and Easterly, 1999) have considered the effects of attitudes toward African Americans on support for welfare, and other scholars have considered how racial and/or ethnic heterogeneity resulting from increases in immigration has reduced support for the welfare state, primarily in Western European countries (cf., Burgoon, Koster, and van Egmund 2010; Eger 2010; Hjerm and Schnabel 2012). Here we focus explicitly on how individuals' evaluation of illegal immigrants, their support for expanded immigration, and a general pro-immigration scale based on a factor analysis of these two items influences individuals' attitudes toward the welfare state. Using data from the 1992-2012 Cumulative American National Election Studies (CANES), we find strong evidence to support our hypotheses about the linkage between individuals' immigration attitudes and their welfare attitudes. We find that the effect of immigration attitudes on welfare attitudes remains even in the face of a wide range of statistical controls and our effort to account for possible endogeneity between immigration attitudes and welfare attitudes, and further this effect is observed in our general sample of the population, among white survey respondents, among both immigrant and non-immigrant families, and in the periods both before and after the 1996 welfare reform act (PRWORA). Our findings are robust across a wide range of conditions and model specifications.

We are particularly struck by the relative magnitude of the effects of immigration attitudes in shaping welfare attitudes, particularly in comparison to the effects of other variables that have long been seen as important determinants of welfare attitudes. An examination of standardized regression coefficients and 
patterns of predicted probabilities reveals that attitudes toward the poor have arguably the strongest effect on welfare attitudes, as one might expect. However, what is interesting is that the effects of attitudes toward immigration are stronger than are the effects of attitudes toward blacks and other variables such as partisan identification, political ideology, and even family income. All in all, it would appear that how Americans think about immigration and immigrants is a major component of how they think about welfare, even in comparison to the effects of other variables found to have important influences on welfare attitudes in previous studies.

Where do we go from here? We suggest that the research agenda on the linkage between immigration attitudes and welfare attitudes is a full one. First, more research should be done using alternative measures of support for the welfare state. We have focused our attention on support for welfare spending, as well as on how Americans think about welfare recipients, but there are other welfare state variables-including support for spending on specific welfare programs - that warrant study. For instance, are Americans more likely to support other government programs within the broad category of "welfare" programs as a function of attitudes toward immigration? We have noted that immigrants and non-immigrants are about equally likely to participate in TANF, SSI, and state cash assistance programs, but immigrants are significantly more likely to participate in food assistance programs and Medicaid. It is worth exploring whether or not attitudes toward immigrants only influence support for food stamps and Medicaid, but not other programs. If so, it provides support for our speculation that it is immigrants' welfare participation that triggers the linkage between immigrant attitudes and welfare attitudes. However, if immigrant attitudes influence public support for all types of welfare programs, the linkage between immigrant attitudes and welfare attitudes might very likely be due to general ideology, misperceptions, stereotypes, and/or prejudice.

Second, it is arguably the case that we need better measures of attitudes toward immigration in order to understand the operational causal mechanism better. In other words, if it is "stereotypes and prejudice" 
of immigrants that renders public support for welfare, it is theoretically interesting to identify what exact kind of stereotype most effectively reduces support for welfare. Furthermore, not only do we need data on how Americans think about illegal or undocumented immigrants, but we also need more specific data on how Americans think about immigrants who are in the United States legally, including permanent residents and naturalized U.S. citizens. Do Americans think differently about immigrants who are here illegally and immigrants who are here as permanent residents or who have earned citizenship? Does how Americans think about these groups affect how they think about the welfare state? Does how Americans think about citizens who are black, Hispanic, white, Asian, or of other racial or ethnic backgrounds affect their attitudes toward the welfare state?

Third, we have not explored in this paper the effects of context, but this is a crucial next step toward developing an understanding of the linkage between immigration attitudes and attitudes toward the welfare system. One argument about why immigration attitudes and welfare attitudes should be linked is that immigrants are more likely to be a part of the welfare system. If this is the explanation for the relationship between immigration attitudes and welfare attitudes, then we would expect survey respondents from those geographic areas in which immigrants are overrepresented among welfare recipients to exhibit the strongest relationship between immigration attitudes and welfare attitudes; in these contexts, welfare is "immigrationized," and individuals residing in those areas should connect their attitudes toward immigrants to their support for the welfare state. This should particularly be the case for individuals who are heavy news media users and who have a high level of political sophistication; these individuals are more likely to be at least roughly cognizant of welfare utilization rates among immigrants and nonimmigrants. Moreover, scholars have explored the effects of racial and ethnic heterogeneity on support for welfare programs, and including contextual data on racial and ethnic heterogeneity would seem to be an important next step in studying how immigration attitudes are related to welfare attitudes. In particular, if racial and ethnic heterogeneity sensitizes individuals to out-groups and their potentially 
greater participation rates in welfare programs, one might expect the effects of immigration attitudes on welfare attitudes to be of stronger magnitude in contexts characterized by high heterogeneity than in homogeneous contexts. 


\section{ENDNOTES}

1. Federal law prohibits immigrants in the United States for less than five years from receiving federal funds from the Temporary Assistance for Needy Families (TANF) program, though states may use their own funds for this subpopulation; what this means is that one would expect participation by immigrants in this traditional "welfare" program to be relatively low. The CPS data compiled by Camarota (2012) reveal that immigrants are approximately equally likely to be recipients of "cash assistance," a category that includes TANF benefits (for immigrants residing in the United States for more than five years), Supplemental Security Income (SSI), and state general assistance (for which immigrants are eligible only according to the laws of their state of residence).

2. Note that these figures represent eligibility, and not receipt of the program. There are many individuals who are eligible for the EITC and ACTC but who do not avail themselves of these programs. 


\section{REFERENCES}

Alesina, Alberto, Reza Baqir, and William Easterly. 1999. "Public Goods and Ethnic Divisions.” Quarterly Journal of Economics 114(4): 1203-50.

Alesina, Alberto and Edward L. Glaeser. 2004. Fighting Poverty in the US and Europe: A World of Difference. Oxford: Oxford University Press.

Banting, Keith and Will Kymlicka. 2005. "Do Multicultural Policies Erode the Welfare State?" In Manuscript Kingston Ontario: Queens University.

Baum, C. F., M. E. Schaffer, and S. Stillman. 2003. "Instrumental variables and GMM: Estimation and testing." Stata Journal 3 (1): 1-31.

Baum, Christopher F., Mark E. Schaffer, and Steven Stillman. 2007. “Enhanced Routines for Instrumental Variables/Generalized Method of Moments Estimation and Testing." Stata Journal 7 (4): 465-506.

Best, Samuel J., and Brian S. Krueger. 2011. “Government Monitoring and Political Participation in the United States: The Distinct Roles of Anger and Anxiety." American Politics Research 39 (1): 85-117.

Brown, Michael. 1999. Race, Money, and the American Welfare State. Ithica: Cornell University Press.

Burgoon, Brian, Ferry Koster, and Marcel van Egmond. 2010. "Support for Redistribution and the Paradox of Immigration." Paper presented at the 2010 annual meeting of the American Political Science Association.

Camarota, Steven A. 2012. "Immigrants in the United States: A Profile of America's Foreign-Born Population." Center for Immigration Studies. Downloaded from http://www.cis.org/sites/cis.org/files/articles/2012/immigrants-in-the-united-states-2012.pdf.

Cuddy, Amy, Susan Fiske, Stephanie Demoulin, \& Jacques-Phillipe Leyens. 2000. "Stereotype content of social groups, as perceived by Belgian respondents." Unpublished data, Princeton University.

Cuddy, Amy, Susan Fiske, Virgina Kwan, Peter Glick, Stephanie Demoulin, Jacques-Phillipe Leyens, Micheal Bond, Jean-Claude Croizet, Naomi Ellemers, Ed Sleebos. 2009. "Is the stereotype content 
model culture-bound? A cross-cultural comparison reveals systemiatic similarities and differences?" British Journal of Social Psychology 48(1), 1-33.

Eger, Maureen A. 2010. "Even in Sweden: The Effect of Immigration on Support for Welfare State Spending." European Sociological Review 26: 203-17.

Gilens, Martin. 2000. Why Americans Hate Welfare: Race, Media, and the Politics of Antipoverty Policy. Chicago: University of Chicago Press.

Gilens, Martin. 2003. "How the Poor Became Black-The Racialization of American Poverty in the Mass Media." In Race and Politics of Welfare Reform, ed. Sanford Schram, Joe Soss and Richard C. Fording. Ann Arbor: The University of Michigan Press.

Gujarati, Domodar N. and Dawn C. Porter. 2012. Basic Econometrics (6 ${ }^{\text {th }}$ edition). New York: McGraw-Hill. Habyarimana, James, Macartan Humphreys, Daniel N. Posner, and Jeremy M. Weinstein. 2007. "Why Does Ethic Diversity Undermine Public Goods Provision?" American Political Science Review 101 (4):709-725. Handler, Joel. 1995. The Poverty of Welfare Reform. New Haven: Yale University Press.

Hanson, Gordon H. 2004. "Immigration Policy." San Diego: University of California, San Diego, and National Bureau of Economic Research.

Hero, Rodney E. , and Robert R. Preuhs. 2007. "Immigration and the Evolving American Welfare State:

Examining Policies in the U.S. States." American Journal of Political Science 51 (3):498-517.

Hjerm, Mikael and Annette Schnabel. 2012. "How Much Heterogeneity Can the Welfare State Endure? The Influence of Heterogeneity on Attitudes to the Welfare State." Nations and Nationalism 18:34669.

Howard, Christopher. 1999. "The American Welfare State or States?" Political Research Quarterly 52:421442.

Hutchison, Marc. 2014. "Tolerating Threat? The Independent Effects of Civil Conflict on Domestic Political Tolerance." Journal of Conflict Resolution 58(5): 797-825. 
Jacoby, William. 1994. "Public Attitudes Towards Government Spending." American Journal of Political Science, 38:336-361.

Johnson, Martin. 2003. "Racial Context, Public Attitudes, and Welfare Effort in the American States." In Sanford Schram, Joe Soss, and Richard C. Fording, ed. Race, Welfare, and the Politics of Reform. Ann Arbor: University of Michigan Press.

Kymlicka, Will and Keith Banting. 2006. "Immigration, Multiculturalism, and the Welfare State." Ethics and International Affairs 20: 281-304.

Larsen, Christian Albrekt. 2011. "Ethnic Heterogeneity and Public Support for Welfare: Is the U.S. Experience Replicated in Britain, Sweden, and Denmark?" Scandinavian Political Studies 34: 332-53.

Liberman, Robert. 1998. Shifting the Color Line: Race and the American Welfare State. Cambridge: Harvard University Press.

Miguel, Edward, and Mary Kay Gugerty. 2005. "Ethnic Diversity, Social Sanctions, and Public Goods in Kenya." Journal of Public Economics 89 (2005):2325-2368.

Miguel, Ted. 1999. Ethnic Diversity, Mobility and School Funding: Theory and Evidence from Kenya. Paper read at The Development Economics Discussion Paper Series, at London.

Mau, Steffen and Christoph Burkhardt. 2009. "Migration and Welfare State Solidarity in Western Europe." Journal of European Social Policy 19: 213-29.

Nelson, Thomas. 1999. "Group Affect and Attribution in Social Policy Opinion. Journal of Politics 61:331362.

Noble, Charles. 1997. Welfare As We Knew It: A Political History of the American Welfare State. Oxford: Oxford University Press.

Orr, Larry. 1976. "Income Transfers as a Public Good: An Application to AFDC." American Economic Review 66:359-371. 
Peffley, Mark, Jon Hurwitz, and Paul Sniderman. 1997. "Racial Stereotypes and Whites' Political Views of Blacks in the Context of Welfare and Crime." American Journal of Political Science 41:30-60.

Plotnick, Robert and Richard Winters. 1985. "A Politico-Economic Theory of Income Redistribution." American Political Science Review 79:458-473.

Sargan, J. 1988. "Testing for misspecification after estimation using instrumental variables." In John Denis Sargan, ed. E. Maasoumi, ed. Contributions to econometrics. Vol. 1. Cambridge: Cambridge University Press.

Soss, Joe, Sanford Schram, Thomas Vartanian, and Erin O'Brien. 2001. "Setting the Terms of Relief: Explaining State Policy Choices in the Devolution Revolution." American Journal of Political Science 45 (2):378-395.

Soss, Joe, Richard Fording, and Sanford Schram. 2011. Disciplining the Poor: Neoliberal Paternalism and Persistent Power of Race. Chicago: University of Chicago Press.

Stock, J. H., and M. Yogo. 2005. "Testing for weak instruments in linear IV regression." In D. W. K. Andrews and J. H. Stock, ed. Identification and Inference for Econometric Models: Essays in Honor of Thomas Rothenberg. 80-108. Cambridge: Cambridge University Press.

Sumino, Takanori. 2013. “Does Immigration Erode the Multicultural Welfare State? A Cross-National Multilevel Analysis of 19 OECD Member States." Journal of Ethnic and Migration Studies. 40: 436-55.

Tiane L. Lee and Susan T. Fiske. 2006. "Not an Outgroup, Not Yet an Ingroup: Immigrants in the Stereotype Content Model." International Journal of Intercultural Relations 3: 751-768.

Wolfe, Alan, and Jyette Klausen. 1997. "Identity Politics and the Welfare State." Social Philosophy and Policy 14 (2):213-255.

Woolridge, Jeffrey M. 2012. Introductory Econometrics: A Modern Approach (5 ${ }^{\text {th }}$ edition). Mason, Ohio: South-Western Cengage. 
U.S. Bureau of the Census. 2013. "America's Foreign Born in the Last 50 Years." Downloaded from https://www.census.gov/how/pdf//Foreign-Born--50-Years-Growth.pdf on March 23, 2014.

U.S. Bureau of the Census. 1999. "Nativity of the Population, for Regions, Divisions, and States: 18501990." Downloaded from http://www.census.gov/population/www/documentation/twps0029/tab13.html on March 23, 2014. Wright, Gerald. 1976. Community Structure and Voting in the South. Public Opinion Quarterly 40:201-215. 


\section{SUPPLEMENTARY MATERIAL}

\section{Appendix 1. Description of Variables}

Variable

Feeling thermometer: welfare recipients

Support for welfare spending (CANES)

Feeling thermometer: illegal immigrants

Support for immigration

Pro-immigration scale

Feeling thermometer: blacks

Feeling thermometer: the poor

Partisan identification

Political ideology

Female respondent

Black respondent

Hispanic respondent

Asian respondent

Education
Description

Feeling thermometer for welfare recipients: $100=$ strong positive affect; . . .; 0 = strong negative affect.

$1=$ respondent supports increases in welfare spending; $0=$ respondent supports keeping welfare spending the same; $-1=$ respondent supports decreases in welfare spending.

Feeling thermometer for illegal immigrants: $100=$ strong positive affect; . . . 0 = strong negative affect.

$1=$ respondent supports increased immigration; $0=$ respondent supports keeping immigration at current levels; -1 = respondent supports decreased immigration.

Scale of immigration attitudes based on principle components factor analysis of feeling thermometer for illegal immigrations and support for immigration. (Eigenvalue $=1.339$, variance explained $=0.670$.)

Feeling thermometer for blacks or African Americans: $100=$ strong positive affect; . . ; 0 = strong negative affect.

Feeling thermometer for the poor: 100 = strong positive affect; .. . 0 = strong negative affect.

7-point partisan identification scale: $6=$ respondent is a strong Republican; . . . ; 0 = respondent is a strong Democrat.

7-point scale of liberal-conservative ideology: $6=$ respondent is a strong conservative; . . ; 0 = respondent is a strong liberal.

$1=$ respondent is a female; $0=$ respondent is a male.

$1=$ respondent is black or African American; 0 = otherwise.

$1=$ respondent is Hispanic or Latino; 0 =otherwise.

$1=$ respondent is Asian; 0 = otherwise.

7 = respondent has post-graduate degree; . . ; 1 = respondent has less than a high school degree 


\section{Appendix 1 (continued)}

Variable

Description

Family income

5-point family income scale: 5 = respondent is in top $5 \%$ of income distribution; . . ; 1 = respondent is in bottom one-sixth of income distribution.

Age

Respondent age (in years)

Church attendance

$4=$ respondent attends church services more than once $a$ week; . . ; 0 = respondent never attends church services.

Warrant for wiretaps

1 = respondent favors the U.S. government being required to present evidence to get a court's permission before it can listen in on phone calls made by American citizens who are suspected of being terrorists; 0 = respondent neither supports or opposes; -1 = respondent opposes warrant requirement.

Limits on foreign imports

1 = respondent favors limits on foreign imports; 0 = respondent has not thought much about this matter; - 1 = respondent opposes limits on foreign imports.

Immigration takes away jobs

$3=$ respondent perceives that it is extremely likely that recent immigration levels will take away jobs from people already here; . . . ; $0=$ respondent perceives that it is not at all likely. 


\section{APPENDIX 2: ROBUSTNESS TESTS}

Our empirical results thus far provide strong support for the assertion that immigration attitudes matter for welfare attitudes. Individuals who adopt pro-immigration attitudes are significantly more favorable in their evaluations of welfare recipients and in their support for welfare spending; conversely, of course, individuals who express anti-immigration views are much more likely to hold less favorable views toward welfare recipients or express less support for welfare spending. This immigration effect is also observed for each of the specific immigration items that comprise our pro-immigration scale. Individuals who express negative affect toward illegal immigrants and/or who support decreased levels of immigration are significantly less favorable toward welfare recipients and welfare spending than others. Our results suggest that Americans link their immigration attitudes and their welfare attitudes. In this section we consider possible limitations or alternative explanations for our findings and offer a series of tests of the robustness of our core findings.

\section{Endogeneity and Reciprocal Causality Issues}

Although our results suggest a strong positive relationship between immigrant attitudes and welfare attitudes, a plausible counter-argument is that this relationship is endogenous and that the observed relationship actually flows from welfare attitudes to immigrant attitudes, and not (as we suggest) the other way around. Our theory has suggested why and how attitudes toward immigrants influence individuals' support for welfare spending and their attitudes toward welfare recipients. Yet it is possible that the causal arrow is in the opposite direction-i.e., individuals' welfare attitudes affect their attitudes toward immigrants and immigration. For instance, individuals who have strong antagonism toward welfare programs may express negative sentiments against anyone who they perceive to be heavy users of those programs. Insofar as individuals may perceive that immigrants are overrepresented in the welfare system, it would not be surprising to see that how Americans think about welfare will shape their immigration attitudes. More importantly, it may be the case that the relationship between 
immigration attitudes and welfare attitudes that we observe here is really an artifact of a pattern of causation in the opposite direction. A statistical model that fails to address the possibility of endogeneity could lead to biased estimates of the effect of immigrant attitudes on welfare attitudes.

In order to address the endogeneity issue, we use two-stage least squares estimation with instrumental variables (IV-2SLS) (Woolridge, 2012; Gujarati and Porter, 2012). Using this instrumental model approach appropriately allows us to estimate the independent effect of immigrant attitudes on welfare attitudes, without the concern that welfare attitudes are unduly influencing our model estimates. The IV-2SLS approach purges the endogenous component from our independent variable immigrant attitudes, and then we are able to assess the degree to which the purged (or instrumented) independent variable continues to have a significant effect on the dependent variable (Baum, Schaffer and Stillman 2007). The IV-2SLS technique requires us to identify instruments that are correlated with the endogenous immigrant attitudes variable but remain independently unrelated to welfare attitudes, once accounting for the other independent variables in the model (Woolridge, 2012; Gujarati and Porter; 2012; Best and Krueger 2011; Hutchison 2014). The IV-2SLS technique permits us to disentangle the causal mechanism in two stages. In the first-stage model the endogenous independent variable (immigrant attitudes) is modelled as a function of the instruments and the other independent control variables; in the second-stage model the dependent variable (welfare attitudes) is modelled as a function of the instrumented immigrant attitudes variable and the control variables. To be confident in a 2SLS result requires three conditions: (1) the instruments must effectively predict the endogenous independent variable and independently account for a significant amount of the variance in the firststage model; (2) the instruments and the error term of the second-stage model should be orthogonali.e., the excluded instruments should not independently predict the dependent variable in the second stage model once controlling for the other variables in the model, and (3) the instrumented 
independent variable should continue to exhibit a relationship with the dependent variable (Baum, Schaffer and Stillman 2007; Woolridge, 2012; Gujarati and Porter, 2012).

Our search for variables that meet the tests for appropriate instrumental variables presents a difficult challenge using data from the CANES. This is a general data set that does not include a wide range of possible instruments for immigration attitudes, and possible instrumental variables are available in some years but not in others. Fortunately, the 2012 American National Election Survey (ANES) includes a wide range of potential instruments. Following the general rules of the IV-2SLS approach, we have identified three variables as exogenous (or excluded) instruments that have no prior theoretical connections with welfare attitudes: (1) support for the requirement that the government be required to obtain a warrant to authorize wiretapping of phone calls by American citizens who are suspected of being terrorists; (2) support for limits on foreign imports; and (3) degree of agreement with the assertion that immigrants take away jobs from "people already here." Given the availability of appropriate instruments, we conduct our IV-2SLS analyses using data from the 2012 ANES. The results from the IV-2SLS analyses indicate that our immigration attitudes variables have a strong effect on welfare attitudes even after we consider possible endogeneity. The 2012 results give us confidence that immigration attitudes should have a similar effect on welfare attitudes in our analyses of CANES data.

In the first stage we estimate a model that depicts our pro-immigration scale as a function of the three instrumental variables as well as the various control variables from our original models. The predicted values represent an instrumented measure of pro-immigration attitudes that is purged of the influence of welfare attitudes. We then use the purged (or instrumented) immigrant attitude variable to predict our two dependent variables: (1) attitudes toward welfare recipients; and (2) support for welfare spending. For each of the two dependent variables, we estimate the first stage model with the same set of instruments. In Model (1), Appendix Table 2.1 we display the results for the second-stage model when we use attitudes toward welfare recipients as the dependent variable, while Model (2) in 
Appendix Table 2.1 we present the results for the second-stage model when we use support for welfare spending as the dependent variable. Results for the first-stage models can be found in Appendix Table 2.2 .

We have conducted two diagnostic tests to determine whether or not our instruments are valid. First, we use the Stock-Yogo weak identification test to determine whether or not these three instruments can sufficiently predict the endogenous independent variable, our pro-immigration scale (Stock and Yogo 2005). The Cragg-Donald F statistic we have obtained is 427.56 for Model (1) (where affect toward welfare recipients is the dependent variable) and 1011.80 for Model (2) (where support for welfare spending is the dependent variable), both of which far exceed the Stock-Yogo weak ID test critical value 9.08 (Stock and Yogo 2005; Baum Schaffer and Stillman 2007). The partial $R^{2}$ values offer an intuitive corroboration of these formal tests that the excluded instruments strongly predict immigration attitudes. The three excluded instruments alone contribute to 0.2195 toward the overall $R^{2}$ of 0.3825 in the first stage model when we use "affect toward welfare recipients" as the DV (see Model 1 of Appendix Table 2.2).The same three excluded instruments also contributed to 0.2214 toward the overall $R^{2}$ of 0.3838 in the first stage model when "support for welfare spending" is used as our DV (see Model 2 of Appendix 2.2). Therefore, we can reject the null hypothesis that our instruments are weak.

In the second test, we assess the possibility that our excluded instruments can predict the error terms from our second-stage models and thus suggest that they independently relate to the dependent variables; the Sargan statistic serves this purpose (Sargan 1988; Baum, Schaffer and Stillman 2003; Baum, Schaffer and Stillman 2007). The Sargan statistic for Model (1) (with affect toward welfare recipients as our dependent variable) is $0.879(p=0.6442)$, which does not approach conventional levels of statistical significance $(p<0.05)$. In Model $(2)$, with support for welfare spending as our dependent variable, the Sargan statistic is $0.230(p=0.9370)$, which also does not meet standard thresholds for statistical significance. Given these results, we have little confidence that the excluded instruments 
could predict the second-stage models' error terms. In other words, the excluded instruments can be safely left out of the second stage models, as they would not independently predict welfare spending attitudes or attitudes toward welfare recipients.

Finally, and most importantly, our results in Appendix Table 2.1 show that the purged (or instrumented) pro-immigration scale still has the expected positive effect on each of the two dependent variables. In Model (1), the coefficient for the instrumented pro-immigration scale $(b=6.414, t=6.28)$ is positive and far surpasses conventional levels of statistical significance, indicating that immigration attitudes have a strong effect on attitudes toward welfare recipients even when we control for endogeneity. After accounting for possible endogeneity, we still find that individuals who hold more favorable attitudes toward immigrants (and immigration) remain significantly and strongly more likely to have positive evaluations of welfare recipients. Moving to Model (2), we find that the instrumented immigrant attitudes variable $(b=0.158, t=4.53)$ has a positive and significant effect on support for welfare spending, meaning that even after accounting for possible endogeneity individuals holding more favorable attitudes toward immigrants will be more likely to support welfare spending.

Taken together, these findings show strong support for a causal arrow that leads from proimmigrant attitudes to welfare attitudes. How Americans think of immigration continues to have a strong, independent effect on their attitudes toward welfare recipients and their support for welfare spending in the United States even after we account for endogeneity.

\section{Stability of immigration attitudes effects across groups}

Another possible concern is that the strong effects of pro-immigration attitudes on welfare attitudes may vary across groups or contexts. While we have found strong evidence of a linkage between immigration attitudes and welfare attitudes in a sample of the general population, it is possible that some groups are especially likely to link these two sets of variables, while others do not make this connection at all or do so very weakly. 
White-only effect? One argument is that the relationship between immigration attitudes and welfare attitudes may be particularly strong among white Americans, who are themselves somewhat underrepresented in the welfare system and may be more likely to see welfare program participantsparticularly those in racial, ethnic, and immigration minority groups-as less deserving. Hence one might expect that the relationship between immigration attitudes and welfare attitudes will be particularly strong among whites. In Appendix Table 2.3 we present estimates of our models of attitudes toward welfare recipients and support for welfare spending, estimated separately for white respondents only. As one can see, the pro-immigration scale has a strong positive effect on both affect toward welfare recipients $(b=4.647, t=17.21)$ and support for welfare spending $(b=0.367, t=10.88)$. We are struck by how the coefficients for the pro-immigration scale are of similar magnitudes in our white-only sample and our all-respondents sample from Model (1), Table 2 and Model (1), Table 3, respectively. It would appear that the strong effect of immigration attitudes on welfare attitudes is not diminished in the sample of only white respondents.

We also conduct the same endogeneity IV-2SLS tests for white respondents only. Our results show strong support for the causal mechanism between immigrant attitudes and welfare attitudes despite the endogeneity issue for white respondents only. Results for whites only for the second and first stages can be found in Appendix Tables 2.4 and 2.5 , respectively.

Immigrant and non-immigrant families. A second source of possible heterogeneity in the effect of immigration attitudes on welfare attitudes can arise from possible differences between those in immigrant and native-born families. We consider the possibility that individuals from native-born families-i.e., those in which both parents were born in the United States-will be particularly sensitive to their immigrant attitudes in shaping their views toward welfare. In Appendix Table 2.6 we present estimates for our model of attitudes toward welfare recipients, estimated separately for native-born families and those families with at least one foreign-born parent; our estimates for our model of support for welfare spending is 
reported in Appendix Table 2.7. For our models of attitudes toward welfare recipients, we find that the effects of pro-immigration attitudes are roughly the same for both native-born families $(b=4.980, t=$ 19.88) and immigrant families $(b=4.636, t=6.70)$. A similar pattern is observed for our models of support for welfare spending; pro-immigration attitudes have a similar effect for individuals from both native-born $(b=0.309, t=9.51)$ and foreign-born $(b=0.453, t=4.82)$ families; if anything, the effect of the proimmigration scale is stronger for individuals from immigrant families than for native-born families. Ultimately, it appears that immigration attitudes have a strong effect on welfare attitudes, regardless of immigration family status.

Pre- vs. post-welfare reform. One other possibility is that the relationship between immigration attitudes and welfare attitudes differs for the time periods prior to and after the adoption of the Personal Responsibility and Work Opportunity Reconciliation Act (1996), which was welfare-reform legislation that, among other things, limited immigrants' access to federally-funded welfare programs. Indeed, PRWORA prohibited the use of federal funds to provide welfare benefits to immigrants in their first five years in the United States, though state governments were free to use their own funds to support immigrants and to determine their own time limits and eligibility criteria. Since immigrants were eligible for welfare programs prior to the implementation of PRWORA, it is possible that the linkage between immigration attitudes and welfare attitudes would be stronger prior to this act; after the act, immigrants were somewhat detached from the welfare system, and Americans may have become less likely to connect their immigration attitudes and welfare attitudes as a result. In Appendix Table 2.8 we estimate our model of attitudes toward welfare recipients separately for the pre- and post-reform periods, and we find that the proimmigration variable has a positive and statistically-significant effect on the dependent variable in both time periods. The coefficient is about one-third higher in the pre-reform period $(b=5.953, t=17.63)$ than in the post-reform period $(b=4.408, t=13.65)$, indicating that immigration attitudes have a somewhat stronger effect in the pre-reform period. In addition, in Appendix Table 2.9 we estimate our model of 
attitudes toward welfare spending separately for the pre- and post-reform periods, and our findings are similar: pro-immigration attitudes have a strong positive effect on attitudes toward welfare spending in both the pre-reform $(b=0.365, t=7.03)$ and post-reform $(b=0.318, t=8.70)$ periods, though the coefficient is moderately higher in the pre-reform period. Overall, it appears that the effect of immigration attitudes on welfare attitudes is powerful both prior to and after PRWORA, though there is a slightly stronger effect in the pre-reform period. These findings point to the relative homogeneity of the effects of immigration attitudes on welfare attitudes, with both pre- and post-reform periods characterized by positive coefficients that easily surpass conventional levels of statistical significance. It would appear that the structural relationship between immigration attitudes and welfare attitudes is relatively unchanged as one moves from the pre-reform to the post-reform period. 
Appendix Table 2.1. Instrumental variables / two-stage least squares (IV-2SLS) estimates for models of support for welfare spending, 2012 American National Election Study

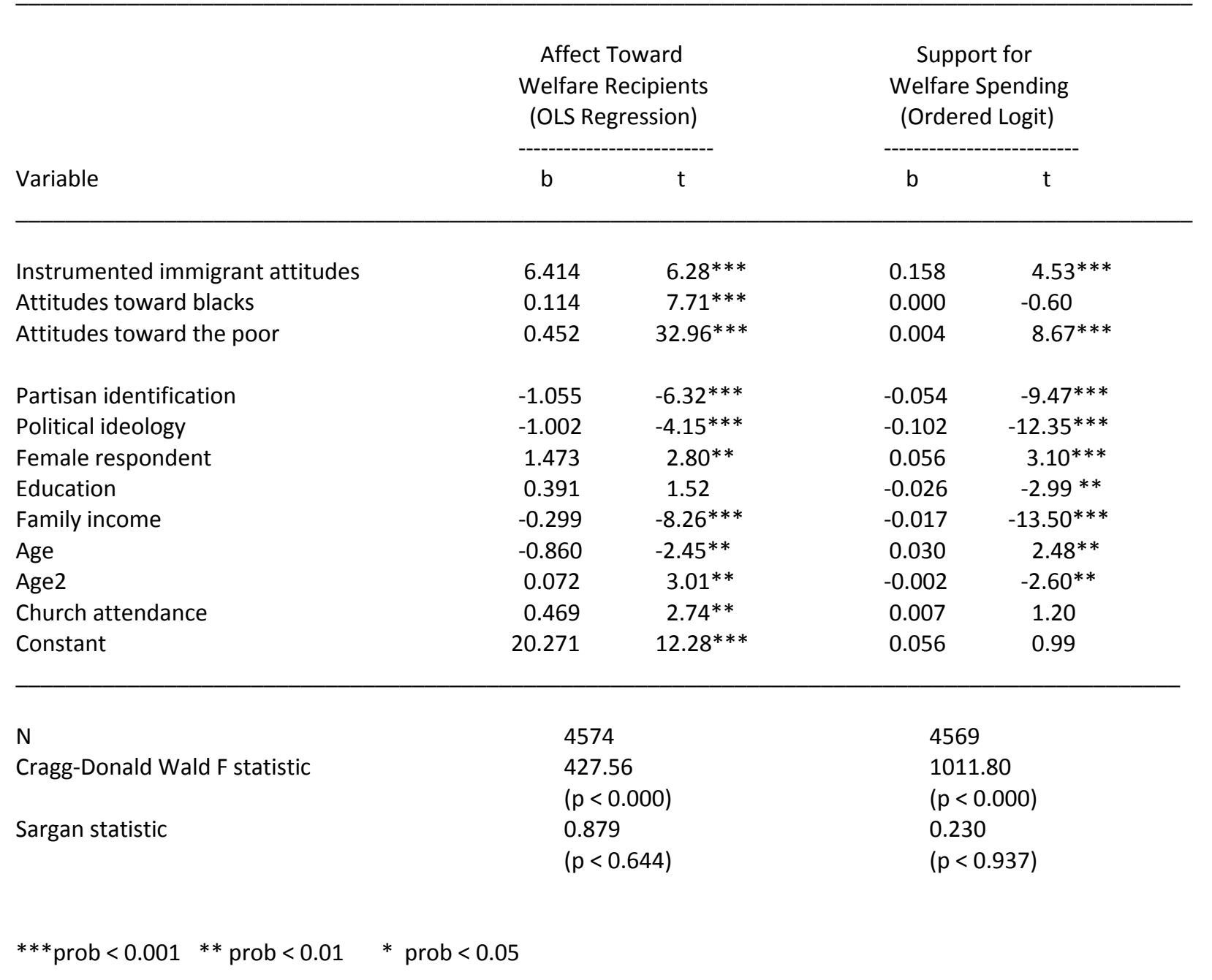


Appendix Table 2.2. First-stage models for instrumental variables / two-stage least squares (2SLS) estimates for models of affect toward welfare recipients and support for welfare spending, 2012 American National Election Study

\begin{tabular}{|c|c|c|c|c|}
\hline \multirow[b]{2}{*}{ Variable } & \multicolumn{2}{|c|}{$\begin{array}{l}\text { Affect Toward } \\
\text { Welfare Recipients } \\
\text { (OLS Regression) }\end{array}$} & \multicolumn{2}{|c|}{$\begin{array}{l}\text { Support for } \\
\text { Welfare Spending } \\
\text { (Ordered Logit) }\end{array}$} \\
\hline & b & $\mathrm{t}$ & $\mathrm{b}$ & $\mathrm{t}$ \\
\hline Warrant for wiretaps & 0.020 & $2.23^{* *}$ & 0.021 & $2.28^{* *}$ \\
\hline Limits on foreign imports & -0.076 & $-7.37^{* * *}$ & -0.076 & $-7.41^{* * *}$ \\
\hline Immigrants take away jobs & -0.258 & $-33.43 * * *$ & -0.260 & $-33.63 * * *$ \\
\hline Attitudes toward blacks & 0.005 & $14.56^{* * *}$ & 0.005 & $14.68 * * *$ \\
\hline Attitudes toward the poor & 0.001 & $3.94 * * *$ & 0.002 & $4.10^{* * *}$ \\
\hline Partisan identification & -0.033 & $-7.50 * * *$ & -0.033 & $-7.60 * * *$ \\
\hline Political ideology & -0.043 & $-6.65 * * *$ & -0.041 & $-6.39 * * *$ \\
\hline Female respondent & -0.027 & -1.84 & -0.026 & -1.79 \\
\hline Education & 0.019 & $2.70 * *$ & 0.017 & $2.48^{* *}$ \\
\hline Family income & 0.000 & 0.15 & 0.000 & 0.23 \\
\hline Age & -0.055 & $-5.83 * * *$ & -0.053 & $-5.62^{* * *}$ \\
\hline Age2 & 0.003 & $4.41 * * *$ & 0.003 & $4.23 * * *$ \\
\hline Church attendance & 0.025 & $5.42^{* * *}$ & 0.026 & $5.55^{* * *}$ \\
\hline Constant & 0.247 & $5.32^{* * *}$ & 0.231 & $4.96^{* * *}$ \\
\hline $\mathrm{N}$ & 457 & & 456 & \\
\hline $\mathrm{R}^{2}$ & 0.3 & & 0.3 & \\
\hline Partial $R^{2}$ & 0.2 & & 0.2 & \\
\hline \multicolumn{5}{|c|}{$\begin{array}{l}\text { Note: The dependent variable in each of these models is the pro-immigration scale. Separate estimates are provided } \\
\text { for the two welfare variables because of differences in sample sizes for the models of affect toward welfare recipients } \\
\text { and support for welfare spending. }\end{array}$} \\
\hline \multicolumn{5}{|c|}{$* * *$ prob $<0.001 * *$ prob $<0.01 *$ prob $<0.05$} \\
\hline
\end{tabular}


Appendix Table 2.3. OLS and ordered logit estimates for models of affect toward welfare recipients and support for welfare spending, white respondents only, selected years (1992-2012), Cumulative American National Election Study

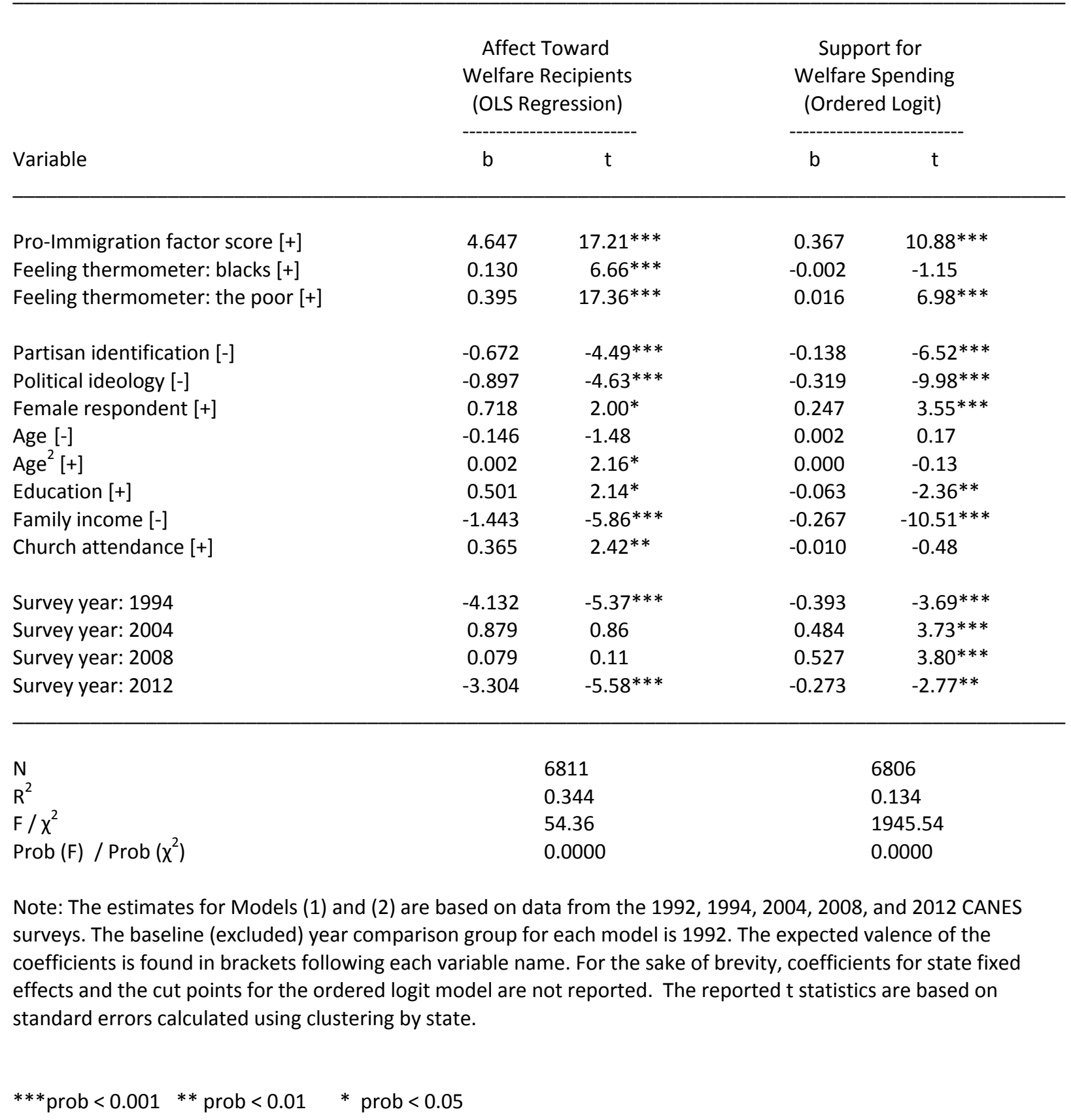


Appendix Table 2.4. Instrumental variables / two-stage least squares (IV-2SLS) estimates for models of affect toward welfare recipients and support for welfare spending, white respondents only, 2012 American National Election Study

\begin{tabular}{|c|c|c|c|c|}
\hline \multirow[b]{2}{*}{ Variable } & \multicolumn{2}{|c|}{$\begin{array}{c}\text { Affect Toward } \\
\text { Welfare Recipients } \\
\text { (OLS Regression) }\end{array}$} & \multicolumn{2}{|c|}{$\begin{array}{l}\text { Support for } \\
\text { Welfare Spending } \\
\text { (Ordered Logit) }\end{array}$} \\
\hline & b & $\mathrm{t}$ & $\mathrm{b}$ & $\mathrm{t}$ \\
\hline Instrumented immigrant attitudes [+] & 8.180 & $7.38^{* * *}$ & 0.226 & $5.96^{* * *}$ \\
\hline Attitudes toward blacks [+] & 0.082 & $4.80^{* * *}$ & -0.002 & $-2.71 * *$ \\
\hline Attitudes toward the poor $[+]$ & 0.467 & $29.25 * * *$ & 0.005 & $8.39 * * *$ \\
\hline Partisan identification [-] & -0.567 & $-2.93 * *$ & -0.042 & $-6.43 * * *$ \\
\hline Political ideology [-] & -1.278 & $-4.51 * * *$ & -0.108 & $-11.23 * * *$ \\
\hline Female respondent $[+]$ & 1.382 & $2.34 * *$ & 0.071 & $3.54 * * *$ \\
\hline Education $[+]$ & 0.394 & 1.37 & -0.021 & $-2.10^{*}$ \\
\hline Family income [-] & -0.249 & $-6.03 * * *$ & -0.016 & $-11.57 * * *$ \\
\hline Age $[-]$ & -0.480 & -1.20 & 0.051 & $3.73 * * *$ \\
\hline $\operatorname{Age}^{2}[+]$ & 0.051 & $1.89 *$ & -0.003 & $-3.75 * * *$ \\
\hline Church attendance $[+]$ & 0.434 & $2.25^{*}$ & 0.003 & 0.46 \\
\hline Constant & 8.551 & $9.84 * * *$ & -0.009 & -0.13 \\
\hline $\mathrm{N}$ & \multicolumn{2}{|c|}{3508} & \multicolumn{2}{|c|}{3505} \\
\hline Cragg-Donald Wald F statistic & \multicolumn{2}{|c|}{$\begin{array}{l}356.43 \\
(p<0.000)\end{array}$} & \multicolumn{2}{|c|}{$\begin{array}{l}353.66 \\
(p<0.000)\end{array}$} \\
\hline Sargan statistic & \multicolumn{2}{|c|}{2.409} & \multicolumn{2}{|c|}{$\begin{array}{l}0.046 \\
(p=0.9773)\end{array}$} \\
\hline
\end{tabular}


Appendix Table 2.5. First-stage models for instrumental variables / two-stage least squares (2SLS) estimates for models of support for welfare spending, white respondents only, 2012 American National Election Study

\begin{tabular}{|c|c|c|c|c|}
\hline \multirow[b]{2}{*}{ Variable } & \multicolumn{2}{|c|}{$\begin{array}{c}\text { Affect Toward } \\
\text { Welfare Recipients } \\
\text { (OLS Regression) }\end{array}$} & \multicolumn{2}{|c|}{$\begin{array}{l}\text { Support for } \\
\text { Welfare Spending } \\
\text { (Ordered Logit) }\end{array}$} \\
\hline & $b$ & $\mathrm{t}$ & $b$ & $\mathrm{t}$ \\
\hline Warrant for wiretaps & 0.157 & 1.55 & 0.016 & 1.62 \\
\hline Limits on foreign imports & -0.072 & $-6.29 * * *$ & -0.071 & $-6.15^{* * *}$ \\
\hline Immigrants take away jobs & -0.272 & $-30.69 * * *$ & -0.271 & $-30.61 * * *$ \\
\hline Attitudes toward blacks & 0.005 & $11.95^{* * *}$ & 0.005 & $12.04 * * *$ \\
\hline Attitudes toward the poor & 0.001 & $3.23 * * *$ & 0.001 & $3.31 * * *$ \\
\hline Partisan identification & -0.028 & $-5.48 * * *$ & -0.029 & $-5.54 * * *$ \\
\hline Political ideology & -0.045 & $-5.97 * * *$ & -0.045 & $-5.87^{* * *}$ \\
\hline Female respondent & -0.032 & $-1.98 *$ & -0.034 & $-2.06 *$ \\
\hline Education & 0.020 & $2.58^{* *}$ & 0.020 & $2.50^{*}$ \\
\hline Family income & 0.001 & 0.64 & 0.001 & 0.69 \\
\hline Age & -0.055 & $-5.10 * * *$ & -0.055 & $-5.01 * * *$ \\
\hline Age2 & 0.003 & $4.12 * * *$ & 0.003 & $4.04 * * *$ \\
\hline Church attendance & 0.023 & $4.41^{* * *}$ & 0.024 & $4.50^{* * *}$ \\
\hline Constant & 0.254 & $4.72 * * *$ & 0.244 & $4.52^{* * *}$ \\
\hline $\mathrm{N}$ & 35 & & 35 & \\
\hline$R^{2}$ & & & 0.3 & \\
\hline Partial $R^{2}$ & & & 0.2 & \\
\hline \multicolumn{5}{|c|}{$\begin{array}{l}\text { Note: The dependent variable in each of these models is the pro-immigration scale. Separate estimates are provided } \\
\text { for the two welfare variables because of differences in sample sizes for the models of affect toward welfare recipients } \\
\text { and support for welfare spending. }\end{array}$} \\
\hline \multicolumn{5}{|c|}{$* * *$ prob $<0.001 * *$ prob $<0.01 *$ prob $<0.05$} \\
\hline
\end{tabular}


Appendix Table 2.6. OLS estimates for models of affect toward welfare recipients, by parents' nativity status, selected years (1992-2012), Cumulative American National Election Study

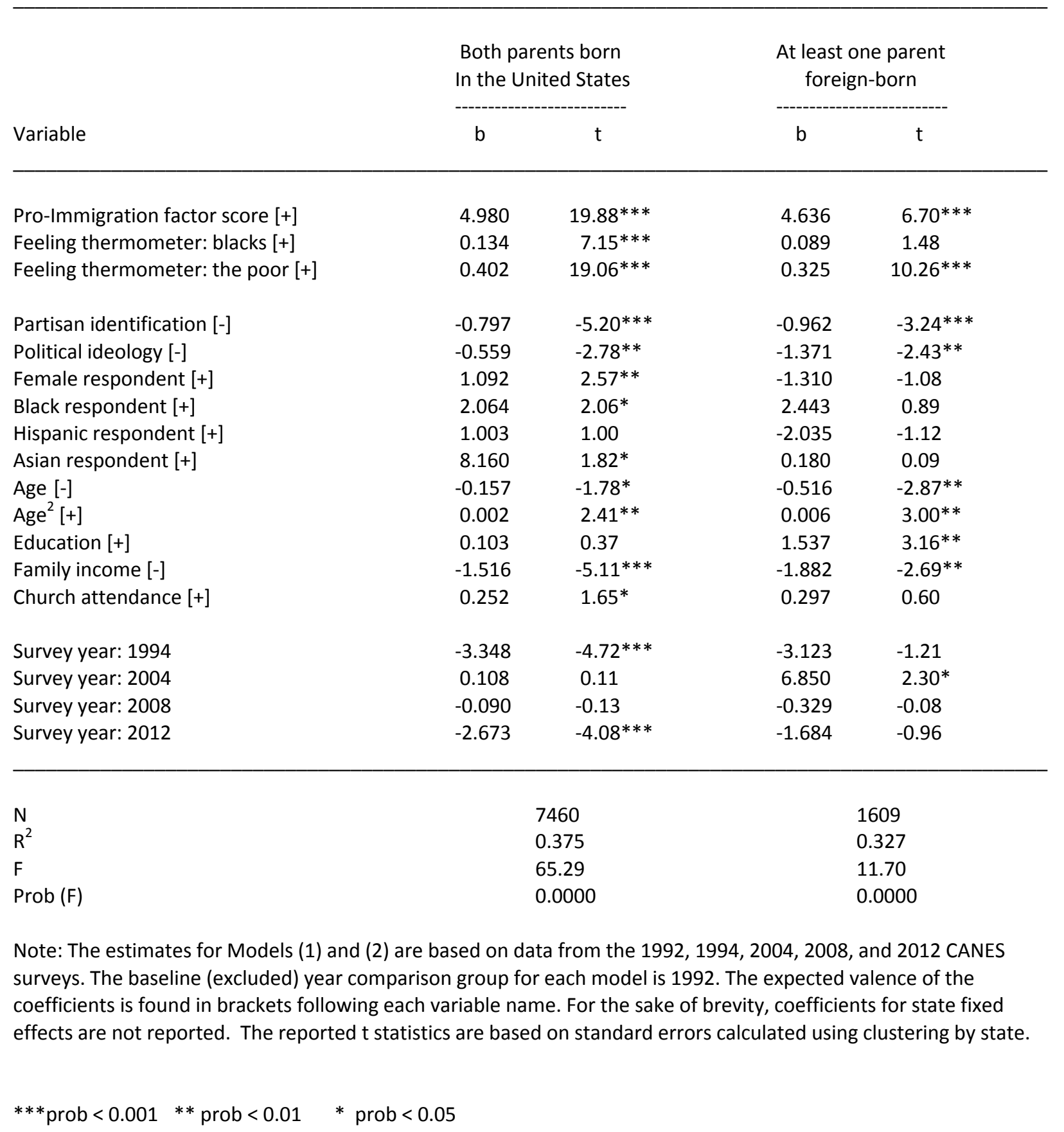


Appendix Table 2.7. Ordered logit estimates for models of support for welfare spending, by parents' nativity status, selected years (1992-2012), Cumulative American National Election Study (CANES)

\begin{tabular}{|c|c|c|c|c|}
\hline \multirow[b]{2}{*}{ Variable } & \multicolumn{2}{|c|}{$\begin{array}{l}\text { Both parents born } \\
\text { In the United States }\end{array}$} & \multicolumn{2}{|c|}{$\begin{array}{l}\text { At least one parent } \\
\text { foreign-born }\end{array}$} \\
\hline & b & $\mathrm{t}$ & $\mathrm{b}$ & $\mathrm{t}$ \\
\hline Pro-Immigration factor score $[+]$ & 0.309 & $9.51 * * *$ & 0.453 & $4.82 * * *$ \\
\hline Feeling thermometer: blacks [+] & 0.000 & -0.21 & -0.012 & $-2.21^{*}$ \\
\hline Feeling thermometer: the poor $[+]$ & 0.016 & $7.37^{* * *}$ & 0.005 & $2.24^{*}$ \\
\hline Partisan identification [-] & -0.136 & $-7.96 * * *$ & -0.200 & $-8.25 * * *$ \\
\hline Political ideology [-] & -0.283 & $-9.72 * * *$ & -0.248 & $-4.50 * * *$ \\
\hline Female respondent $[+]$ & 0.252 & $4.02 * * *$ & 0.035 & 0.22 \\
\hline Black respondent $[+]$ & 0.469 & $4.60 * * *$ & 0.226 & 0.80 \\
\hline Hispanic respondent [+] & 0.243 & $1.95^{*}$ & -0.098 & -0.52 \\
\hline Asian respondent $[+]$ & 0.705 & 1.09 & -0.351 & -1.45 \\
\hline Age $[-]$ & 0.001 & 0.13 & -0.012 & -0.80 \\
\hline $\operatorname{Age}^{2}[+]$ & 0.000 & 0.06 & 0.000 & 0.46 \\
\hline Education [+] & -0.067 & $-2.27^{*}$ & -0.006 & -0.10 \\
\hline Family income [-] & -0.257 & $-11.12^{* * *}$ & -0.366 & $-5.83 * * *$ \\
\hline Church attendance $[+]$ & -0.026 & -1.43 & 0.071 & $1.87 *$ \\
\hline Survey year: 1994 & -0.268 & $-2.48^{* *}$ & -0.903 & $-3.51 * * *$ \\
\hline Survey year: 2004 & 0.370 & $2.43^{* *}$ & 0.888 & $2.84 * *$ \\
\hline Survey year: 2008 & 0.499 & $3.83^{* * *}$ & 1.003 & $3.04 * *$ \\
\hline Survey year: 2012 & -0.263 & $-2.72 * *$ & -0.191 & -1.43 \\
\hline $\mathrm{N}$ & & 7457 & & \\
\hline Pseudo- $R^{2}$ & & 0.134 & & \\
\hline$\chi^{2}$ & & 2085.22 & & .51 \\
\hline $\operatorname{Prob}\left(\chi^{2}\right)$ & & 0.0000 & & 000 \\
\hline \multicolumn{5}{|c|}{$\begin{array}{l}\text { Note: The estimates for Models (1) and (2) are based on data from the 1992, 1994, 2004, 2008, and } 2012 \text { CANE } \\
\text { surveys. The baseline (excluded) year comparison group for each model is 1992. The expected valence of the } \\
\text { coefficients is found in brackets following each variable name. For the sake of brevity, coefficients for state fixe } \\
\text { effects and the cut points from the ordered logit models are not reported. The reported t statistics are based o } \\
\text { standard errors calculated using clustering by state. }\end{array}$} \\
\hline
\end{tabular}


Appendix Table 2.8. OLS estimates for models of affect toward welfare recipients, by pre- or post-reform period, selected years (1992-2012), Cumulative American National Election Study

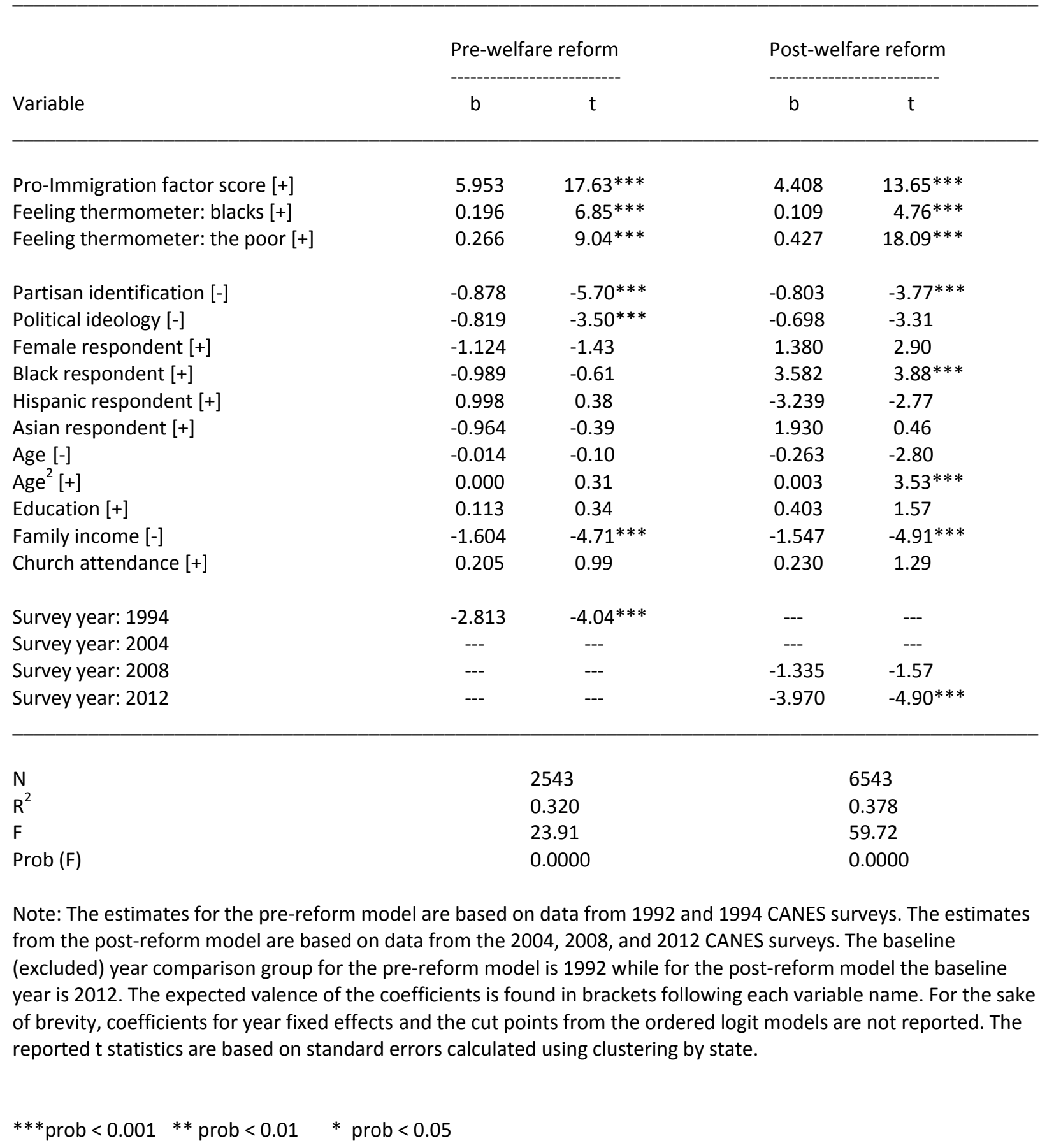


Appendix Table 2.9. Ordered logit estimates for models of support for welfare spending, by pre- or post-reform period, selected years (1992-2012), Cumulative American National Election Study (CANES)

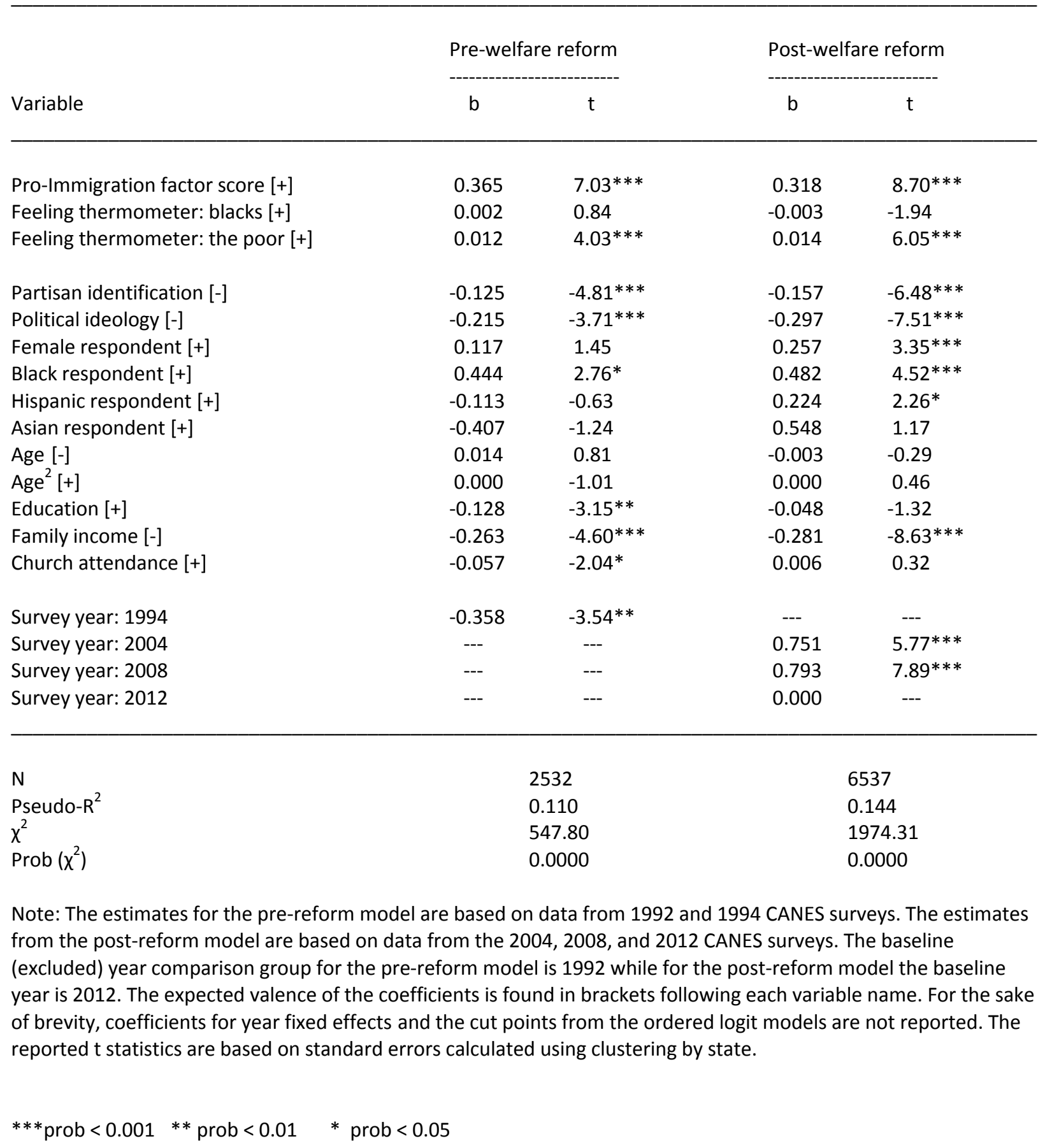

